\title{
Synthesis, Stability Constant Determination, and Structural Study of Some Complexes of a Zinc Triad Containing Pyridyl-amine-quinoline and Pyridyl- thio-quinoline
}

\author{
Luciano Canovese, ${ }^{*[a]}$ Fabiano Visentin, ${ }^{[a]}$ Gavino Chessa, ${ }^{\text {[a] }}$ Carlo Levi, ${ }^{[a]}$ and \\ Alessandro Dolmella ${ }^{[b]}$
}

Keywords: Zinc / Quinoline-based ligands / Fluorescence / Formation constants

The potentially fluorescent and terdentate ligands containing nitrogen or sulfur as coordinating atom were synthesized and used in the formation of perchlorate or chloride complexes of the metals of the $\mathrm{Zn}$ triad. The reaction of the ligands with metal perchlorate salts yields the corresponding bis-chelate derivatives, whereas the same ligands react with metal chloride salts to give monochelate complexes. All of these complexes undergo NMR-scale fast fluxional rearrangement in solution. Some structural X-ray diffractometric studies were also performed and the ensuing data confirm the surmised structures and the solution rearrangement in the case of monochelate substrates and of one $\mathrm{Hg}$ derivative, respec- tively. The equilibrium constants of formation in the case of monochelate derivatives were also determined in water by means of spectrophotometric titration of the studied ligand with the metal ions. The values of the equilibrium constants were confirmed by supplementary determination taking into account the exchange between two different metals and/or dissociation equilibria. The fluorescence activity of ligands and complexes was eventually studied and notably one fluorescent silent ligand gives rise to fluorescent zinc derivatives.

( Wiley-VCH Verlag GmbH \& Co. KGaA, 69451 Weinheim, Germany, 2007)

\section{Introduction}

The bioactivity of group-12 metal ions is well known, the toxic effects of mercury and cadmium on living organisms being widely recognized. ${ }^{[1]}$ On the contrary zinc is present in traces in many enzymes and consequently it must be considered a bio-compatible metal at least when its concentration is confined within the millimolar range. ${ }^{[2]}$ High concentrations of zinc could, however, entail pollution problems when industrial or human wastes in restricted areas are involved.

In this respect, the synthesis of new ligands with remarkable coordinating capabilities represents an important step for the development of chemical devices for the field monitoring of several metal ions. ${ }^{[3-10]}$ For this reason, we decided to synthesize a series of new polydentate ligands and test their versatility in the identification of the group-12 metals when present in different concentrations and situations.

The synthesized ligands are reported in Scheme 1. We chose to analyze the coordinating capability of the ligands

[a] Department, Dipartimento di Chimica, Università Ca’ Foscari, Calle Larga S. Marta 2137, 30123 Venezia, Italy Fax: +39-412348517

E-mail: cano@unive.it

[b] Dipartimento di Scienze Farmaceutiche, Università di Padova, Via F. Marzolo 5, 35131 Padova, Italy

$\square$ Supporting information for this article is available on the WWW under http://www.eurjic.org or from the author. toward proton and metals in distilled water and in the presence of chloride ions since we aim at using these substrates directly in marine or lagoon waters.<smiles>CCCCCN(C)SCc1ccccn1</smiles><smiles>O=[N+]([O-])Nc1cccc2cccnc12</smiles><smiles>Cc1ccc(S(=O)(=O)N(Cc2ccccn2)c2cccc3cccnc23)cc1</smiles>

Scheme 1.

It is well known that quinoline displays remarkable properties as a photophysical fluorescent chromophore ${ }^{[11]}$ and as a coordinating agent towards many transition-metal ions. 
Therefore, the synthesis of polydentate ligands bearing quinoline together with other potentially coordinating atoms could represent an important target in a strategy aiming at low cost and easy identification of several analytes.

\section{Results and Discussion}

\section{General Remarks}

Owing to the low solubility of the ligands and related complexes in water, all determinations of equilibrium constants were performed without ionic strength control since any addition of inert salt induces massive precipitation under our experimental conditions (i.e. the solubility of the $\mathrm{Hg}$ complexes in $0.01 \mathrm{M} \mathrm{NaClO}_{4}$ dramatically drops to about $1 \times 10^{-6} \mathrm{moldm}^{-3}$ ). For this reason we have determined the complex formation equilibrium constants by means of the UV/Vis technique, any potentiometric approach being inadequate. We therefore chose to privilege the use of water as solvent instead of controlling the ionic strength in mixed solvents since we expect that the ligands we synthesized should be used as metal probes in natural and waste waters.

\section{Synthesis of the Ligands}

The ligands NSN(Py) $\{\mathrm{NSN}(\mathrm{Py})=2-[(2-$ pyridylmethyl $)-$ thio]pyridine $\},{ }^{[12 a]} \mathrm{NNN}$ tos(Qui) [NNNtos(Qui) $=8-\mathrm{N}$-tosyl- $N$-(2-pyridylmethyl)quinoline] and NSN(Qui) [NSN(Qui) = 8-[(2-pyridylmethyl)thio]quinoline], were synthesized according to published procedures ${ }^{[12 \mathrm{~b}]}$ the ligand NNN(Qui) $\{$ NNN(Qui) = 8-[(2-pyridylmethyl) amino]quinoline was obtained by removing the tosyl group from the NNNtos(Qui) moiety by acid hydrolysis with concentrated $\mathrm{H}_{2} \mathrm{SO}_{4}$ at $110{ }^{\circ} \mathrm{C}$.

\section{Synthesis of the Complexes}

\section{Bis-Chelate Complexes}

Addition of the perchlorate salt $\mathrm{M}\left(\mathrm{ClO}_{4}\right)_{2}(\mathrm{M}=\mathrm{Zn}, \mathrm{Cd}$, $\mathrm{Hg}$ ) to the ligand $\mathrm{LL}^{\prime} \mathrm{L}^{\prime \prime}\left[\mathrm{LL}^{\prime} \mathrm{L}^{\prime \prime}=\mathrm{NNN}(\right.$ Qui), NNNtos(Qui), NSN(Qui)] in acetonitrile or methanol yields the corresponding complex of general formula $\left[\mathrm{M}\left(\mathrm{LL}^{\prime} \mathrm{L}^{\prime \prime}\right)_{2}\right]-$ $\left(\mathrm{ClO}_{4}\right)_{2}$.

The complexes of $\mathrm{Hg}$ and $\mathrm{Cd}$ with the ligand NSN are characterized by the down-field shift of the $\mathrm{CH}_{2} \mathrm{~S}$ protons and the concomitant high-field shift of the aromatic protons $\mathrm{H}^{2}$ and $\mathrm{H}^{2}$. This phenomenon had already been observed, ${ }^{[13]}$ and was traced back to the interactions occurring between the ring currents of the opposite rings of the bis coordinated ligand. A down-field shift of the aromatic protons would be otherwise observed upon ligand coordina- tion. Moreover, in these complexes the $\mathrm{CH}_{2} \mathrm{~S}$ protons resonate as a singlet and no $\left({ }^{199} \mathrm{Hg}^{1} \mathrm{H}\right)$ and $\left({ }^{111 / 113} \mathrm{Cd}{ }^{1} \mathrm{H}\right)$ coupling even at the lowest temperature achievable $(233 \mathrm{~K})$ was observed. The lack of any observable coupling constants could be traced back to the small value of the constant itself or to the rapid exchange of the ligand among complexes. The authors, however, on the basis of their own experience with these kinds of ligands and according to previous observations, ${ }^{[14]}$ are inclined to believe that the ligands in these cases are not firmly bound to the central metal and that a fluxional rearrangement affects these complexes in solution. As a matter of fact, the solid-state structure of the complex $\left[\mathrm{Hg}(\mathrm{NSN})_{2}\left(\mathrm{OClO}_{3}\right)\right] \mathrm{ClO}_{4}$ was clearly produced by the displacement of one terminus of the potentially terdentate ligand (the quinoline nitrogen) by the oxygen of a perchlorate ion. Usually, the solid-state structure of a species cannot be considered as a warranty of its solution behavior. However, in this case the displacement of a nitrogen terminus must be definitely promoted by the rearrangement of the complex itself in solution. Furthermore, the lack of diastereotopicity of the $\mathrm{CH}_{2} \mathrm{~S}$ protons indicates that the rate of sulfur absolute configuration inversion is fast with respect to the NMR time scale. The NNN(Qui) derivatives behave very similarly to those of the NSN ligand. Also in these cases no coupling between $\mathrm{Hg}, \mathrm{Cd}$, and protons is observed, the aromatic protons $\mathrm{H}^{2}$ and $\mathrm{H}^{2}$ resonate at higher field with respect to the free ligand in both the complexes; no diastereotopicity was observed for $\mathrm{CH}_{2} \mathrm{~N}$ protons which, however, resonate at field values very similar to those of the free ligand. The complexes $\left[\mathrm{Zn}\left(\mathrm{LL}^{\prime} \mathrm{L}\right)_{2}\right]-$ $\left(\mathrm{ClO}_{4}\right)_{2}\left[\mathrm{LL}^{\prime} \mathrm{L}=\mathrm{NSN}(\mathrm{Qui}), \mathrm{NNN}(\right.$ Qui) $)$ behave similarly. However, the $\mathrm{H}^{2}$ and $\mathrm{H}^{2^{\prime}}$ protons of the complex $\left[\mathrm{Zn}[\mathrm{NSN}(\mathrm{Qui})]_{2}\right]\left(\mathrm{ClO}_{4}\right)_{2}$ resonate down field with respect to the free ligand, apparently no interference between the ring currents being operative in this case.

The most prominent features of the bis-chelate derivatives of the ligand NNNtos(Qui) are the diastereotopicity of the $\mathrm{CH}_{2} \mathrm{~N}$ protons and the signals due to the $\mathrm{H}^{2}$ and $\mathrm{H}^{2}$ protons which resonate downfield with respect to the free ligand. The tosyl group in planar tetra-coordinated complexes was shown to lie almost perpendicular to the main complex coordination plane thereby inducing an asymmetry in the $\mathrm{sp}^{3} \mathrm{CH}_{2} \mathrm{~N}$ protons which give rise to an $\mathrm{AB}$ system when the rearrangement movement is slow in the NMR time scale. ${ }^{[12]}$ All the ${ }^{1} \mathrm{H}$ NMR spectra of complexes $[\mathrm{M}\{\mathrm{NNNtos}(\mathrm{Qui})\}]\left(\mathrm{ClO}_{4}\right)_{2}(\mathrm{M}=\mathrm{Hg}, \mathrm{Cd}, \mathrm{Zn})$ display for the $\mathrm{CH}_{2} \mathrm{~N}$ protons an $\mathrm{AB}$ system indicating a slow rearrangement of the tosyl wing around the metal center. The down-field resonance of the aromatic $\mathrm{H}^{2}$ and $\mathrm{H}^{2}$ protons is also detected in the case of $\mathrm{Hg}$ and $\mathrm{Cd}$ complexes with NNNtos(Qui) but, probably because of the compensating effect of the tosyl fragment which is orthogonal to the complex main plane, no interactions between ring currents are observable.

Moreover, in the cases of the $\mathrm{Hg}$ and $\mathrm{Cd}$ derivatives, the ${ }^{1} \mathrm{H}$ NMR low-temperature spectra display the ${ }^{199} \mathrm{Hg}^{1} \mathrm{H}$ and ${ }^{111 / 113} \mathrm{Cd}^{1} \mathrm{H}$ coupling for the signals due to the $\mathrm{CH}_{2} \mathrm{~N}$ and $\mathrm{H}^{2}$ and $\mathrm{H}^{2}$ protons. 


\section{Monochelate Dichloro Complexes}

Addition of the ligand $\mathrm{LL}^{\prime} \mathrm{L}^{\prime \prime}$ [LL'L" = NSN(Qui), $\mathrm{NNN}$ (Qui), NNNtos(Qui)] to $\mathrm{MCl}_{2}(\mathrm{M}=\mathrm{Hg}, \mathrm{Cd}, \mathrm{Zn})$ in methanol yields the corresponding monochelate dichloro complexes of general formula $\left[\mathrm{M}\left(\mathrm{LL}^{\prime} \mathrm{L}^{\prime \prime}\right) \mathrm{Cl}_{2}\right]$. In any case a general down-field shift of the ligand signals of the $\mathrm{CH}_{2} \mathrm{~S}$, $\mathrm{CH}_{2} \mathrm{~N}$, and aromatic protons is observed upon coordination. The $\mathrm{CH}_{2} \mathrm{~N}$ shift for both the NNN ligands is less pronounced being almost isochronous with that of the free ligand. The lack of a high-field shift of the $\mathrm{H}^{2}$ and $\mathrm{H}^{2 \prime}$ aromatic protons induced by the currents of the opposite rings represents a useful clue to monochelation.

\section{X-ray Crystal Structure}

The ORTEP ${ }^{[15]}$ representations of the complexes $\left[\mathrm{Hg}\{\mathrm{NSN}(\mathrm{Qui})\} \mathrm{Cl}_{2}\right]$ (1), $\left[\mathrm{Hg}\{\mathrm{NSN}(\mathrm{Qui})\}_{2}\left(\mathrm{OClO}_{3}\right)\right]\left(\mathrm{ClO}_{4}\right)$ (2), and $\left[\mathrm{Zn}\{\mathrm{NNN}(\mathrm{Qui})\} \mathrm{Cl}_{2}\right]$ (3) together with the employed numbering schemes are shown in Figures 1, 2, and 3 , respectively. Complexes $\mathbf{1}$ and $\mathbf{3}$ are neutral and five-coordinate; complex $\mathbf{2}$ is cationic and six-coordinate.
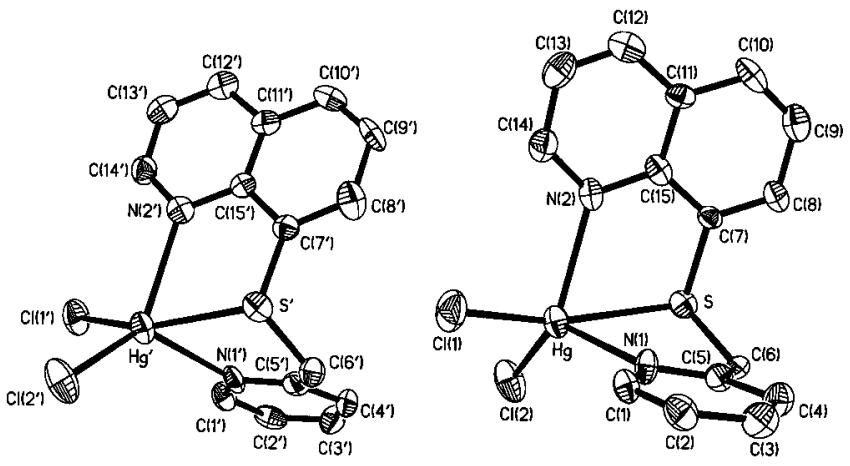

Figure 1. Anisotropic ellipsoid representation of the TBPY-5-12-C (right) and TBPY-5-12-A (left) units of complex 1. The thermal ellipsoids are drawn at the $40 \%$ probability level. Hydrogen atoms have been omitted.

Five-coordinate complexes $\mathbf{1}$ and $\mathbf{3}$ : In complexes $\mathbf{1}$ and 3 the environment of the metal is given by a tridentate [NSN(Qui) or NNN(Qui)] ligand and by two chloride ions. Notably, in the unit cell of $\mathbf{1}$ there are two crystallographically independent complexes that are mirror images without forming, however, an enantiomeric pair (see below). The coordination geometry of both units appears intermediate between square pyramidal $(s p)$ and trigonal bipyramidal $(t b p)$, while it is square pyramidal in $\mathbf{3}$. The $\tau$ angular structural index ${ }^{[16]}$ (ideal values: 0 for $s p$ and 1 for $t b p$ geometry) was used to measure the deviation from either one of the ideal arrangements in $\mathbf{1}$ and $\mathbf{3}$. In the two units of $\mathbf{1} \tau=$ 0.59 and $\tau=0.45$ (average 0.52 ), whereas $\tau=0.01$ in 3 . Accordingly, we considered the two units of 1 like distorted $t b p$ complexes. In this description, the apical positions around $\mathrm{Hg}$ are taken by the $\mathrm{Cl}(1)$ chloride and by the $\mathrm{S}$ atom of the chelate ligand, while the equatorial plane is filled by the $\mathrm{Cl}(2), \mathrm{N}(1)$, and $\mathrm{N}(2)$ atoms. In 3, the $\mathrm{Cl}(1)$ chloride takes the apical position above $\mathrm{Zn}$ and the basal plane is filled by the $\mathrm{Cl}(2), \mathrm{N}(1), \mathrm{N}(2)$, and $\mathrm{N}(3)$ atoms.

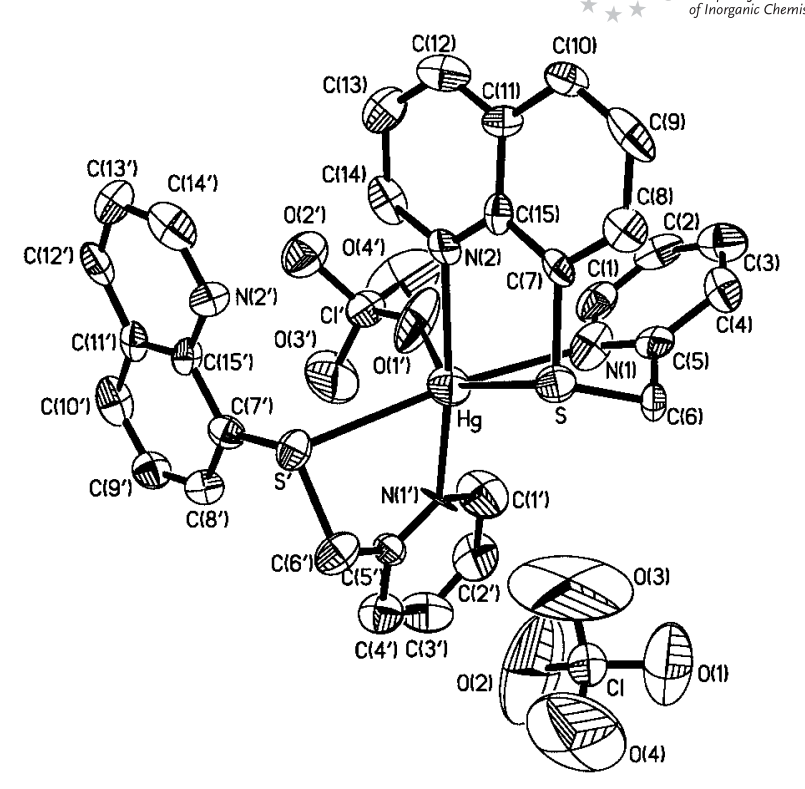

Figure 2. Anisotropic ellipsoid representation of complex 2. The thermal ellipsoids are drawn at the $40 \%$ probability level. Hydrogen atoms have been omitted.

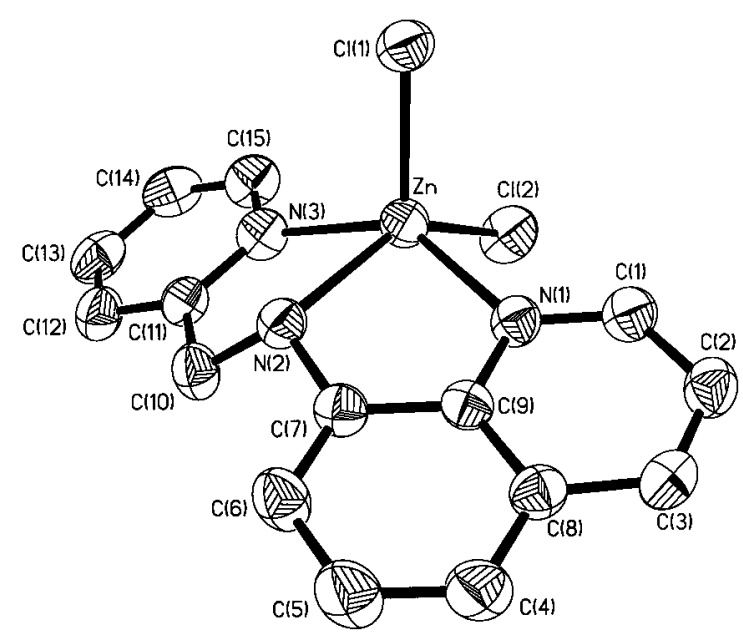

Figure 3. Anisotropic ellipsoid representation of complex 3. The thermal ellipsoids are drawn at the $40 \%$ probability level. Hydrogen atoms have been omitted.

For the sake of clarity, in the remaining part of the discussion the two units of 1 will be named TBPY-5-12-C and $T B P Y-5-12-A$, following the IUPAC ${ }^{[17]}$ recommendations for determining the absolute configuration in inorganic compounds and the CIP (Cahn, Ingold, and Prelog) priority rules. ${ }^{[18]}$ As noticed above, the two units are not alike and the difference becomes clear by comparing the angles $\mathrm{Cl}(1)-\mathrm{Hg}-\mathrm{S}, \mathrm{N}(1)-\mathrm{Hg}-\mathrm{N}(2)$ (imposed by chelation), $\mathrm{N}(1)$ $\mathrm{Hg}-\mathrm{Cl}(1), \mathrm{N}(2)-\mathrm{Hg}-\mathrm{Cl}(1)$, and $\mathrm{S}-\mathrm{Hg}-\mathrm{Cl}(2)$, whose values are 163.1(1), 95.2(3), 97.5(3), 94.6(3), and 90.8(1) ${ }^{\circ}$ in $T B P Y-$ 5-12- $C$ and 156.5(1), 97.2(4), 93.8(3), 89.4(3), and 97.1(1) in $T B P Y-5-12-A$, respectively. The $\mathrm{Hg}$ atom also deviates from the equatorial plane by $0.42 \AA$ in $T B P Y-5-12-C$ and $0.31 \AA$ in $T B P Y-5-12-A$. In 3, the departure of the $\mathrm{Zn}$ atom 
from the basal plane is even larger $(0.66 \AA)$ and such deviation implies that all the $\mathrm{Cl}(1)-\mathrm{Zn}$-equatorial donor angles are well above $90^{\circ}$ (from 104.8 to $111.9^{\circ}$ ).

Our findings were compared with data taken from the Cambridge Crystallographic Database (CCD). ${ }^{[19]}$ We searched the repository looking for (a) five-coordinate monomeric $\mathrm{Hg}^{\mathrm{II}}$ complexes containing a thioether ligand, (b) five-coordinate monomeric $\mathrm{Hg}^{\mathrm{II}}$ complexes containing at least two pyridine-like ligands, (c) five-coordinate $\mathrm{Zn}^{\mathrm{II}} \mathrm{com}-$ plexes containing at least two pyridine-like ligands and an $\mathrm{N}_{3} \mathrm{Cl}_{2}$ coordination set. Search (a) returned nine entries. In these structures, the $\mathrm{Hg}^{\mathrm{II}}-\mathrm{S}$ (thioether) distances vary from $2.491^{[20]}$ to $2.822^{[21]} \AA$. The values found in TBPY-5-12-C and $T B P Y-5-12-A$ [2.759(4) and 2.748(3) $\AA$, respectively] fit in the range and are close to those of the cations described in the literature ${ }^{[21,22]}(2.731$ and $2.727 \AA$, respectively).

Search (b) yielded 13 entries, in which the reported $\mathrm{Hg}^{\mathrm{II}}$ $\mathrm{N}$ (pyridyl) distances vary from $2.235^{[23]}$ to $2.619^{[24]} \AA$. The values found in TBPY-5-12-C and TBPY-5-12- $A$ are 2.350(9), 2.44(1) $\AA$ and 2.38(1), 2.44(1) $\AA$, respectively [the longer $\mathrm{Hg}^{\mathrm{II}}-\mathrm{N}$ bond always involving $\mathrm{N}(2)$ ], again within the experimental range, and are similar to those found in the cation reported in ref. ${ }^{[25]}(2.363,2.401 \AA)$ and in the neutral complexes reported in ref. ${ }^{[26]}(2.373,2.400 \AA)$ and ref. ${ }^{[27]}(2.372,2.429 \AA)$. The $\mathrm{Hg}-\mathrm{Cl}$ distances are 2.455(4), $2.450(3) \AA$ in $T B P Y-5-12-C$ and $2.494(4), 2.428(4) \AA$ in $T B P Y-5-12-A$. The longer $\mathrm{Hg}-\mathrm{Cl}$ bond always involves the $\mathrm{Cl}(1)$ trans to $\mathrm{S}$. These data agree with $\mathrm{CCD}$ values for 35 five-coordinate complexes (2.238-3.029 $\AA$ ).

It is worth noting that complexes in which a five-coordinate $\mathrm{Hg}^{\mathrm{II}}$ is surrounded at the same time by pyridyl and thioether ligands are rather uncommon. ${ }^{[22,25]}$ Recently, Bebout and co-workers ${ }^{[14]}$ described some zinc triad complexes (with c.n. $=4,5$, or 6 ) of a symmetric $\mathrm{N}, \mathrm{S}$ mixed ligand (L) closely related to $\mathrm{NSN}$ (Qui). The $\mathrm{Hg}-\mathrm{N}, \mathrm{Hg}_{-} \mathrm{S}$ distances found in $\mathbf{1}$ fit reasonably well with the values quoted by Bebout for six-coordinate $\mathrm{Hg}^{\mathrm{II}}$ complexes with pyridyl $(2.352-2.557 \AA)$ or crown-thioether ligands (2.458$2.751 \AA$ ), whereas the $\mathrm{Hg}-\mathrm{Cl}$ terminal bonds are somewhat longer than those reported for either four-coordinate $\mathrm{Hg}$ (L) $\mathrm{Cl}_{2}[2.4049(8), 2.4099(8) \AA]$ or five-coordinate $\mathrm{Hg}_{2}(\mathrm{~L}) \mathrm{Cl}_{4}$

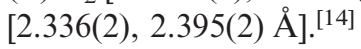

Search (c) returned about 20 entries, but only 11 of these show an aliphatic amine donor atom like 3 . In the reported structures, the $\mathrm{Zn}-\mathrm{N}_{\mathrm{py}}, \mathrm{Zn}-\mathrm{N}_{\mathrm{ali}}\left(\mathrm{N}_{\mathrm{py}}=\right.$ pyridine nitrogen, $\mathrm{N}_{\text {ali }}=$ aliphatic amine nitrogen), and $\mathrm{Zn}-\mathrm{Cl}$ distances vary, respectively, in the ranges $2.039^{[28]}-2.511,{ }^{[28]} 2.129^{[29]}$ $2.464,{ }^{[30]}$ and $2.220^{[30]}-2.345^{[29]} \AA$. In 3, the $\mathrm{Zn}-\mathrm{N}_{\text {py }}$ bonds are 2.124(3), 2.156(3) $\AA, \mathrm{Zn}-\mathrm{N}_{\text {ali }}$ is 2.234(3) $\AA$, and the $\mathrm{Zn}-$ $\mathrm{Cl}$ distances are 2.252(1) and 2.343(1) $\AA$, respectively. The longer $\mathrm{Zn}-\mathrm{Cl}$ bond involving the $\mathrm{Cl}(2)$ chloride trans to the aliphatic amine $\mathrm{N}(2)$ appears to be the second longest reported so far after $2.345 \AA$ in ref. ${ }^{[29]}$. An overall arrangement about $\mathrm{Zn}$ similar to that of $\mathbf{3}$ is found in the complexes described in ref. ${ }^{[31,32]}$ and to a lesser degree in those reported in refs. ${ }^{[29,33]}$

The chloride ligands of $\mathbf{1}$ and $\mathbf{3}$ are involved in a network of nonbonding interactions, which appears to be more ex- tended in $\mathbf{1}$. The intermolecular contacts are listed in detail in Table 2SI of the Supporting Information. The packing diagram of $\mathbf{1}$ also reveals that the quinoline rings of adjacent molecules are stacked in the solid state. The stacking occurs along the crystallographic $a$ axis, in a head-to-tail arrangement. The separation between the planes is $3.47 \AA$ as compared to $3.40 \AA$ in graphite.

Six-coordinate complex 2: In this cation (Figure 2) one of the two NSN(Qui) donors acts as tridentate and the other one as bidentate. The coordination position that is not occupied by the quinolyl $\mathrm{N}$ atom is taken by a perchlorate anion. This situation is unusual, and to the best of our knowledge, in the CCD there is no structure of general formula $\left[\mathrm{M}\left(\mathrm{LL}^{\prime} \mathrm{L}\right)_{2}\right]\left(\mathrm{M}=\right.$ six-coordinate metal, $\mathrm{L}, \mathrm{L}^{\prime}=\mathrm{N}$, $\mathrm{S}$ or $\mathrm{O}, \mathrm{LL}^{\prime} \mathrm{L}=$ tridentate ligand forming with the metal two adjacent five-membered rings) showing a similar arrangement. The uncommon coordinating behavior shown by one NSN donor might be due, at the first glance, to somewhat greater steric demand of the perchlorate anion, compared to the chloride one in $\mathbf{1}$. However, we also suspect that the expected $\left[\mathrm{Hg}\{\mathrm{NSN}(\mathrm{Qui})\}_{2}\right]\left(\mathrm{ClO}_{4}\right)_{2}$ was represented by the colorless specimen of $\mathbf{2}$ that we could not characterize by X-ray diffraction (see Experimental Section). We will try to clarify this issue in future investigations.

The coordination environment around $\mathrm{Hg}$ is distorted octahedral. The dihedral angle formed by the face N(1), $\mathrm{N}(2), \mathrm{S}$ with the triangle opposed to it is $30.5^{\circ}$ (ideal value $\left.=0^{\circ}\right)$. The base plane is defined by the $\mathrm{N}(1), \mathrm{N}(2), \mathrm{N}\left(1^{\prime}\right)$ and $\mathrm{S}^{\prime}$ atoms. The largest deviation from this plane is shown by $\mathrm{N}\left(1^{\prime}\right)(-0.15 \AA)$, while $\mathrm{Hg}$ itself deviates by $+0.20 \AA$. The severe distortion of the octahedron is mainly due to the narrow $\mathrm{S}-\mathrm{Hg}-\mathrm{O}\left(1^{\prime}\right)$ angle $\left[144.1(3)^{\circ}\right]$ and to the variability in $\mathrm{Hg}-\mathrm{N}$ distances. In fact, in the tridentate $\mathrm{NSN}(\mathrm{Qui}) \mathrm{Hg}-\mathrm{N}(1)$ 2.63(1) $\AA, \mathrm{Hg}-\mathrm{N}(2) 2.28$ (1) $\AA$, while in the bidentate $\mathrm{NSN}(\mathrm{Qui}) \mathrm{Hg}-\mathrm{N}\left(1^{\prime}\right)$ 2.23(1) $\AA$. Likewise, in the tridentate donor, the $\mathrm{Hg}-\mathrm{S}-\mathrm{C}(6)$ and $\mathrm{Hg}-\mathrm{S}-\mathrm{C}(7)$ angles are 97.1 and $96.1^{\circ}$, respectively, while the $\mathrm{Hg}-\mathrm{S}^{\prime}-\mathrm{C}\left(6^{\prime}\right)$ and $\mathrm{Hg}-\mathrm{S}^{\prime}-\mathrm{C}\left(7^{\prime}\right)$ angles in the bidentate unit are 87.7 and $113.1^{\circ}$, respectively.

A comparison with existing data was made searching the $\mathrm{CCD}$ repository for (a) six-coordinate monomeric $\mathrm{Hg}^{\mathrm{II}}$ complexes containing a thioether ligand, (b) six-coordinate monomeric $\mathrm{Hg}^{\mathrm{II}}$ complexes with the metal surrounded by at least four pyridyl ligands. Search (a) returned ten entries, in which the $\mathrm{Hg}^{\mathrm{II}}-\mathrm{S}$ (thioether) distance varies between $2.458^{[34]}$ and $3.050^{[34]} \AA$. In 2, there is a shorter and a longer $\mathrm{Hg}-\mathrm{S}$ bond [2.621(4) $\AA$ and 2.749(5) $\AA$ ], a situation already found by Bebout ${ }^{[14]}$ [bonds of 2.654(1) and 2.671(1) $\AA$ ] and also quite similar to what was observed in the complexes described in ref. ${ }^{[35]}$ (bonds of 2.654, 2.735, 2.639, $2.751 \AA$ ) and ref. ${ }^{[36]}$ (distances of 2.728, 2.638, and $2.712 \AA$ ).

Search (b) returned eight entries, with $\mathrm{Hg}^{\mathrm{II}}-\mathrm{N}$ (pyridyl) distances ranging from $2.271^{[37]}$ to $2.685^{[38]} \AA$. The shorter and longer $\mathrm{Hg}-\mathrm{N}$ distances found in 2 [2.23(1), 2.28(1), 2.63(1) $\AA$ ] again fit into the experimental range, with the shorter bond being in fact the shortest $\mathrm{Hg}-\mathrm{N}$ (pyridyl) bond so far reported, about $0.04 \AA$ shorter than the one reported 
in ref. ${ }^{[37]}(2.271 \AA)$, and the longer one being the second longest after the one found in ref. ${ }^{[38]}(2.685 \AA)$. A similar situation with shorter and longer $\mathrm{Hg}-\mathrm{N}$ distances has been reported by Bebout ${ }^{[14]}$ [2.382(4), 2.409(4) $\AA, 2.501(4)$, 2.511(4) $\AA]$ as well as in the cation described in ref. ${ }^{[39]}$ (2.351, 2.418, $2.413 \AA$ ). Taken all together, these data suggest that the asymmetry of the ligand and the steric requirements of the quinolyl moiety are responsible for the NSN(Qui) donor failing to bind mercury in a bis-tridentate fashion as well as for the variation in the $\mathrm{Hg}-\mathrm{S}, \mathrm{Hg}-\mathrm{N}$ bond lengths (Scheme 2).

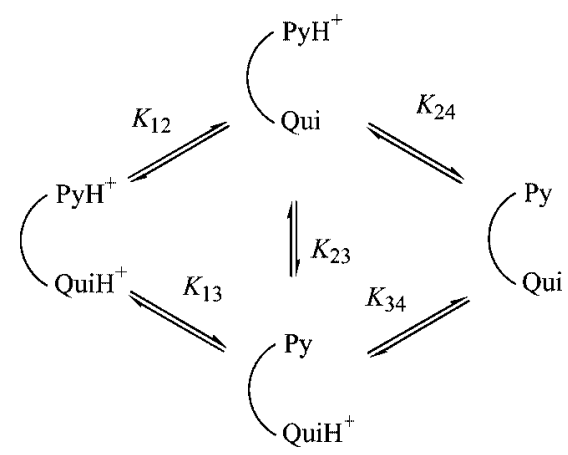

Scheme 2.

It is also worth noting that the perchlorate ligand is rather unusual in $\mathrm{Hg}^{\mathrm{II}}$ complexes. A search in the $\mathrm{CCD}$ returned only five structures, in which the $\mathrm{Hg}-\mathrm{O}$ distance ranges between 2.569 and $2.932 \AA$. The only six-coordinate $\mathrm{Hg}$ complex reported ${ }^{[13]}$ shows $\mathrm{Hg}-\mathrm{O}$ distances of 2.569 and $2.650 \AA$, comparing well with our value of 2.60(1) $\AA$. Like in $\mathbf{1}$ above, the oxygen atoms of the two perchlorate residues and the quinolyl $\mathrm{N}$ atom of the bidentate NSN(Qui) donor are involved in a network of nonbonding interactions. The intermolecular contacts are detailed in Table 2SI.

\section{Determination of the Acid Dissociation Constants}

The determination of the acid dissociation constants of the ligands was performed by potentiometric titration with $\mathrm{NaOH}(0.1 \mathrm{M})$ of the conjugated acids of the ligand

Table 1. Macroconstant set determined by titration with $\mathrm{NaOH}$ $(0.1 \mathrm{M})$ of the acid $\mathrm{LLL} \cdot n \mathrm{HCl}(n=2,3)$ in degassed water $(I=0.1)$ at $25^{\circ} \mathrm{C}$.

\begin{tabular}{llll}
\hline $\mathrm{LL}^{\prime} \mathrm{L}^{\prime \prime} \cdot n \mathrm{HCl}$ & $\mathrm{p} K a_{3}$ & $\mathrm{p} K a_{2}$ & $\mathrm{p} K a_{1}$ \\
\hline $\mathrm{NSN}(\mathrm{Py}) \cdot 2 \mathrm{HCl}$ & $/$ & $3.33 \pm 0.04$ & $5.23 \pm 0.02$ \\
$\mathrm{NSN}(\mathrm{Qui}) \cdot 2 \mathrm{HCl}$ & $/$ & $2.98 \pm 0.14$ & $4.83 \pm 0.03$ \\
$\mathrm{NNN}(\mathrm{Qui}) \cdot 3 \mathrm{HCl}$ & $<2$ & $2.80 \pm 0.13$ & $4.84 \pm 0.02$ \\
\hline
\end{tabular}

[NNN(Qui)·3HCl; NSN(Qui)·2HCl; NSN(Py)·2HCl] produced in situ by addition of the stoichiometric amount of $\mathrm{HCl}(0.1 \mathrm{M})$ in degassed water at controlled ionic strength $(0.1 \mathrm{M}, \mathrm{NaCl})$ under $\mathrm{N}_{2}$ stream. The $\mathrm{pH}$ vs. titrant volume data were elaborated by means of routines appropriately written in the SCIENTIST ${ }^{\mathrm{TM}}$ environment. The macroconstant and microconstant sets are referred for each ligands to the following general schemes and are reported in Tables 1 and 2, respectively (see Supporting Information).

$$
\begin{aligned}
& \mathrm{LL}^{\prime} \mathrm{L}^{\prime \prime} \mathrm{H}_{3}{ }^{3+}+\mathrm{H}_{2} \mathrm{O} \rightleftharpoons \mathrm{LL}^{\prime} \mathrm{LH}_{2}{ }^{2+}+\mathrm{H}_{3} \mathrm{O}^{+} \\
& \mathrm{p} K_{a 3}\left[\mathrm{LL}^{\prime} \mathrm{L}^{\prime \prime} \rightleftharpoons \mathrm{NNN}(\mathrm{Qui})\right] \\
& \mathrm{LL}^{\prime} \mathrm{L}^{\prime \prime} \mathrm{H}_{2}{ }^{2+}+\mathrm{H}_{2} \mathrm{O} \rightleftharpoons \mathrm{LL}^{\prime} \mathrm{LH}^{+}+\mathrm{H}_{3} \mathrm{O}^{+} \\
& \mathrm{p} K_{a 2}\left[\mathrm{LL}^{\prime} \mathrm{L}^{\prime \prime} \rightleftharpoons \mathrm{NNN}(\mathrm{Qui}), \mathrm{NSN}(\mathrm{Qui}), \mathrm{NSN}(\mathrm{Py})\right] \\
& \mathrm{LL}^{\prime} \mathrm{L}^{\prime \prime} \mathrm{H}^{+}+\mathrm{H}_{2} \mathrm{O} \rightleftharpoons \mathrm{LL} \mathrm{L}+\mathrm{H}_{3} \mathrm{O}^{+} \\
& \mathrm{p} K_{a 1}\left[\mathrm{LL}^{\prime} \mathrm{L}^{\prime \prime} \rightleftharpoons \mathrm{NNN}(\mathrm{Qui}), \mathrm{NSN}^{\prime}\right. \text { (Qui), NSN(Py)] }
\end{aligned}
$$

\section{Determination of the Formation Equilibrium Constants}

Hg

The spectrophotometric titration of the ligand $\mathrm{NNN}$ (Qui) with $\mathrm{HgCl}_{2}$ was performed in water and resolved by means of the HYPERQUAD ${ }^{\mathrm{TM}} 2003$ program $^{[40]}$ according to the model:

$$
\begin{aligned}
& \mathrm{Hg}^{2+}+2 \mathrm{Cl}^{-} \rightleftharpoons \mathrm{HgCl}_{2} \\
& \log K_{1}=13.22 \pm 0.2^{[41]} \\
& \mathrm{Hg}^{2+}+2 \mathrm{Cl}^{-}+\mathrm{NNN}(\text { Qui }) \rightleftharpoons\left[\mathrm{Hg}\{\mathrm{NNN}(\text { Qui })\} \mathrm{Cl}_{2}\right] \\
& \log K_{2}=18.56 \pm 0.01 \\
& \mathrm{Hg}^{2+}+2 \mathrm{Cl}^{-}+2 \mathrm{NNN}(\text { Qui }) \rightleftharpoons\left[\mathrm{Hg}\{\mathrm{NNN}(\text { Qui })\}_{2} \mathrm{Cl}_{2}\right] \\
& \log K_{3}=23.52 \pm 0.02
\end{aligned}
$$

It is apparent that the formation of the species in solution is influenced by the ligand/ $\mathrm{Hg}$ ratio and by the equilibrium constants, equilibrium (3) being the most favored at high $\mathrm{NNN}(\mathrm{Qui}) / \mathrm{Hg}$ ratios. The formulation of the complex $\left[\mathrm{Hg}\{\mathrm{NNN}(\mathrm{Qui})\}_{2} \mathrm{Cl}_{2}\right]$ does not imply any structural preference since several attempts to produce crystals suitable for $\mathrm{X}$-ray collection were unsuccessful and a mixture of uncharacterized products was always obtained. According to the structure of $\left[\mathrm{Hg}\{\mathrm{NSN}(\mathrm{Qui})\}_{2}\left(\mathrm{OClO}_{3}\right)\right]\left(\mathrm{ClO}_{4}\right)(2)$ and to the chloride coordinating characteristics, we suggest that this species could be represented as a neutral six-coordinate octahedral complex bearing two partially coordinated $\mathrm{NNN}$ (Qui) fragments and two chlorides. The $\mathrm{pH}$ of the unbuffered solution hardly deviates from 6.5 and therefore no protonation equilibrium of the ligand occurs (see Supporting Information) and no formation of mercury hydroxide is observed. Moreover, owing to the stability of the $\mathrm{HgCl}_{2}$ species the equilibrium constants are better described as shown in equations 4 and 5 .

Table 2. Microconstant set determined by titration with $\mathrm{NaOH}(0.1 \mathrm{M})$ of the acid $\mathrm{LL}^{\prime} \mathrm{L}^{\prime \prime} \cdot n \mathrm{HCl}(n=2,3)$.

\begin{tabular}{llllll}
\hline In degassed water $(I=0.1)$ at $25^{\circ} \mathrm{C}$ & $\mathrm{p} K_{12}$ & $\mathrm{p} K_{13}$ & $\mathrm{p} K_{24}$ & $\mathrm{p} K_{34}$ & $\mathrm{p} K_{23}$ \\
\hline $\mathrm{NSN}(\mathrm{Py}) \cdot 2 \mathrm{HCl}$ & $3.63 \pm 0.16$ & $3.63 \pm 0.16$ & $4.93 \pm 0.02$ & $4.93 \pm 0.02$ & $0.00 \pm 0.03$ \\
$\mathrm{NSN}($ Qui) $\cdot 2 \mathrm{HCl}$ & $3.09 \pm 0.02$ & $3.63 \pm 0.04$ & $4.72 \pm 0.19$ & $4.18 \pm 0.21$ & $0.54 \pm 0.06$ \\
$\mathrm{NNN}($ Qui) $\cdot 3 \mathrm{HCl}$ & $2.87 \pm 0.02$ & $3.63 \pm 0.04$ & $4.77 \pm 0.17$ & $4.01 \pm 0.19$ & $0.76 \pm 0.06$ \\
\hline
\end{tabular}


$\mathrm{HgCl}_{2}+\mathrm{NNN}($ Qui $) \rightleftharpoons\left[\{\mathrm{HgNNN}(\right.$ Qui $\left.)\} \mathrm{Cl}_{2}\right]$

$\log K_{4}=5.34 \pm 0.21\left(\log K_{4}=\log K_{2}-\log K_{1}\right)$

$\mathrm{HgCl}_{2}+2 \mathrm{NNN}($ Qui $) \rightleftharpoons\left[\mathrm{Hg}\{\mathrm{NNN}(\text { Qui })\}_{2} \mathrm{Cl}_{2}\right]$

$\log K_{5}=10.30 \pm 0.22\left(\log K_{5}=\log K_{3}-\log K_{1}\right)$

As a matter of fact the complex $\left[\mathrm{Hg}\{\mathrm{NNN}\right.$ (Qui) $\left.\} \mathrm{Cl}_{2}\right]$ in solution dissociates according to step (4) but at variance with zinc (vide infra) the dissociation constant (ca. $6 \times 10^{-6}$ ) is badly determined owing to the unfavorable change of absorbance as a function of concentration.

The equilibrium constants between mercury and the NSN ligands were also determined in a similar way and a summary of the results is reported in the following Table 3.

Table 3. $\log K_{2}, \log K_{3}, \log K_{4}$, and $\log K_{5}$ for the reaction of $\mathrm{HgCl}_{2}$ with terdentate NNN or NSN ligands in $\mathrm{H}_{2} \mathrm{O}$ at $25^{\circ} \mathrm{C}$.

\begin{tabular}{lllll}
\hline Ligand & $\log K_{2}$ & $\log K_{3}$ & $\log K_{4}$ & $\log K_{5}$ \\
\hline NNN(Qui) & $18.56 \pm 0.01$ & $23.52 \pm 0.02$ & $5.34 \pm 0.21$ & $10.30 \pm 0.22$ \\
NSN(Qui) & $18.84 \pm 0.04$ & $23.52 \pm 0.04$ & $5.62 \pm 0.24$ & $10.30 \pm 0.24$ \\
NSN(Py) & $18.60 \pm 0.07$ & $22.95 \pm 0.13$ & $5.38 \pm 0.27$ & $9.73 \pm 0.33$ \\
\hline
\end{tabular}

As can be seen the equilibrium constant values are hardly influenced by the nature of the chelating ligands. However, only some complexes of the ligands NNNtos(Qui) and NNN(Qui) display fluorescence activity, the latter being the more soluble species; for this reason we decided to extend our investigation on zinc and cadmium using NNN(Qui) as the complexing agent.

\section{$Z n$}

Analogously to the $\mathrm{Hg}$ case the values of the equilibrium constants were determined by direct titration of a ca. $1 \times 10^{-4} \mathrm{moldm}^{-3}$ solution of the ligand $\mathrm{NNN}$ (Qui) with $\mathrm{ZnCl}_{2}$. The model fitted by means of the HYPERQUAD ${ }^{\mathrm{TM}}$ 2003 program $^{[40]}$ was as shown in equations $1^{*}$ to $3^{*}$.

$\mathrm{Zn}^{2+}+2 \mathrm{Cl}^{-} \rightleftharpoons \mathrm{ZnCl}_{2}$

$\log K_{I}^{*}=1^{[41]}$

$\mathrm{Zn}^{2+}+\mathrm{NNN}($ Qui $) \rightleftharpoons[\mathrm{Zn}\{\mathrm{NNN}(\text { Qui })\}]^{2+}$

$\log K_{2}^{*}=4.58 \pm 0.02$

$\mathrm{Zn}^{2+}+2 \mathrm{NNN}(\mathrm{Qui}) \rightleftharpoons\left[\mathrm{Zn}\{\mathrm{NNN}(\mathrm{Qui})\}_{2}\right]^{2+}$

$\log K_{3}^{*}=8.50 \pm 0.04$

As can be seen, chloride does not compete efficiently with oxygenated ligands $\left(\mathrm{H}_{2} \mathrm{O}\right)$, thus the zinc complexes were written with vacant coordination sites which might be occupied by $\mathrm{H}_{2} \mathrm{O}, \mathrm{Cl}^{-}$, and $\mathrm{OH}^{-}$, the latter being the less probable since $\mathrm{p} K_{a} \mathrm{Zn}\left(\mathrm{H}_{2} \mathrm{O}\right)_{x}{ }^{2+} \approx 9$.

At variance with mercury, reaction $2 *$ can be checked by studying the dissociation of the complex [Zn\{NNN(Qui) $\}]^{2+}$ taking place upon dilution. In this case the favorable absorbance change allows the determination of $1 / K_{2}{ }^{*}$ $=1 \times 10^{-5}\left(\log K_{2}^{*}=5 \pm 0.5\right)$ which is in substantial agreement with the value of $\log K_{2}^{*}=4.58$ previously determined.

Moreover, it is possible to study the direct exchange between the $\mathrm{Hg}$ complex and $\mathrm{Zn}\left(\mathrm{ClO}_{4}\right)_{2}$ according to the reaction $4^{*}$.
$\left[\mathrm{Hg}\{\mathrm{NNN}(\mathrm{Qui})\} \mathrm{Cl}_{2}\right]+\mathrm{Zn}^{2+} \rightleftharpoons[\mathrm{Zn}\{\mathrm{NNN}(\mathrm{Qui})\}]^{2+}+\mathrm{HgCl}_{2} \quad$ (4*) $\left.^{*}\right)$ $\log K_{4}^{*}=-0.92 \pm 0.03$

From reactions 4 and $4^{*}$ the value of $\log K_{2}{ }^{*}=$ $4.42 \pm 0.24$ is obtained.

It is apparent that an internal consistency among the $K_{2}{ }^{*}$ values is achieved. Thus, according to the previous choice the value of $\log K_{2}^{*}=4.58 \pm 0.02$ is assumed.

\section{Cd}

The direct exchange between the species [ $\mathrm{Zn}\{\mathrm{NNN}$ (Qui) $\}]^{2+}$ and $\mathrm{Cd}^{2+}$ according to the model described below. Reaction $1^{* *}$ can be treated as a combination of $2^{*}$ and $3 * *$.

$[\mathrm{Zn}\{\mathrm{NNN}(\mathrm{Qui})\}]^{2+}+\mathrm{Cd}^{2+} \rightleftharpoons[\mathrm{Cd}\{\mathrm{NNN}(\mathrm{Qui})\}]^{2+}+\mathrm{Zn}^{2+} \quad\left(1^{* *}\right)$

$\mathrm{Zn}^{2+}+\mathrm{NNN}($ Qui $) \rightleftharpoons[\mathrm{Zn}\{\mathrm{NNN}(\text { Qui })\}]^{2+}$

$\log K_{2}^{*}=4.58 \pm 0.02$

$\mathrm{Cd}^{2+}+\mathrm{NNN}($ Qui $) \rightleftharpoons[\mathrm{Cd}\{\mathrm{NNN}(\text { Qui })\}]^{2+}$

$\log K_{3}^{* *}=2.99 \pm 0.01$

In this respect from the titration of a dechlorinated solution of $[\mathrm{Zn}\{\mathrm{NNN}(\mathrm{Qui})\}]^{2+}$ (from $\left[\mathrm{Zn}(\mathrm{NNN}(\mathrm{Qui})) \mathrm{Cl}_{2}\right]$ treated with $\left.\mathrm{AgClO}_{4}\right)$ with $\mathrm{Cd}\left(\mathrm{ClO}_{4}\right)_{2}$ it is possible to obtain the logarithm of the formation constant $K_{3}^{* *}$ as the refined parameter, the formation constant for zinc $K_{2}{ }^{*}$ being held constant $(4.58 \pm 0.02)$ throughout the fitting process. The chloride ions were removed from the solution in order to avoid formation of cadmium complexes containing chloride bridges which might complicate the resolution of the system. Moreover, no precipitation problems arise under these conditions.

As an internal check of consistency the direct titration of $\mathrm{Cd}^{2+}\left\{\mathrm{Cd}\left(\mathrm{ClO}_{4}\right)_{2}\right\}$ with $\mathrm{NNN}$ (Qui) ligand was also performed and the value of $2.89 \pm 0.01$ for $\log K_{3}^{* * *}$ was determined by means of the customary HYPERQUAD ${ }^{\mathrm{TM}}$ 2003 program. ${ }^{[40]}$ In the presence of an excess of NNN(Qui) ligand a further equilibrium takes place.

$\mathrm{Cd}^{2+}+2 \mathrm{NNN}($ Qui $) \rightleftharpoons\left[\mathrm{Cd}\{\mathrm{NNN}(\text { Qui })\}_{2}\right]^{2+}$

$\log K_{4}^{* *}=6.31 \pm 0.08$

The independently determined values for $K_{3}^{* * *}$ are in good agreement with each other, this fact confirming the model reliability and the consistency of the different approaches.

The equilibrium constants measured in the cases of $\mathrm{Zn}^{2+}$ and $\mathrm{Cd}^{2+}$ complexes lie among the values reported in the literature when di(2-pyridyl)amine and bis[(2-pyridyl)methyl]amine are used as ligands. ${ }^{[42]}$ The case of $\mathrm{Hg}^{2+}$ complexes turns out to be more difficult to compare since the data in the literature are referred to complexes without chloride. The $\log K_{3}$ value $(23.52 \pm 0.02)$, however, is in substantial agreement with that found by other authors when $\mathrm{Hg}\left(\mathrm{NO}_{3}\right)_{2}$ is reacting with bis[(2-pyridyl)methyl]amine. ${ }^{[42]}$ In this respect it is noteworthy that the ionic strength control in the titration of the ligand with $\mathrm{HgCl}_{2}$ is irrelevant since only neutral molecules are involved. 
The titration spectra and the values of the extinction coefficients are reported in the Supporting Information (Table 3SI).

\section{Spectroscopic Properties of the Ligands}

The spectral features of the ligands $\mathrm{NNN}$ (Qui) and NSN(Qui) in different solvents are summarized in Table 4.

Table 4. Absorption and emission $\left(\lambda_{\text {exc }}=320 \mathrm{~nm}\right)$ maxima and fluorescence quantum yields of the ligands $\mathrm{NNN}(\mathrm{Qui})$ and NSN(Qui) in different solvents.

\begin{tabular}{lllll}
\hline Ligand & Solvent & $\lambda_{\text {abs }}[\mathrm{nm}]$ & $\lambda_{\text {em }}[\mathrm{nm}]$ & $\Phi$ \\
\hline NNN(Qui) & $n$-hexane & 260 & 426 & $<0.001$ \\
& & 365 & & \\
& $\mathrm{CH}_{3} \mathrm{CN}$ & 258 & 489 & $0.020 \pm 0.002$ \\
& $\mathrm{H}_{2} \mathrm{O}$ & 252 & - & - \\
NSN(Qui) & $n$-hexane & 253 & 380 & $0.010 \pm 0.001$ \\
& & 340 & & \\
& $\mathrm{CH}_{3} \mathrm{CN}$ & 251 & 420 & $0.020 \pm 0.002$ \\
& & 332 & & \\
& $\mathrm{H}_{2} \mathrm{O}$ & 248 & 453 & $0.10 \pm 0.01$ \\
& & 317 & & \\
\hline
\end{tabular}

The most prominent spectral changes observed at increasing solvent polarity for both ligands are the following: i) a marked blue shift of the first $\pi \pi^{*}$ absorption band, ii) a red shift of the fluorescence emission with a concomitant increase of the Stokes shift, and iii) an increase of fluorescence quantum yields. These changes are consistent with a stabilization of both the ground and the first excited singlet state by polar solvents. ${ }^{[43]} \mathrm{NNN}$ (Qui) is fluorimetrically silent in $\mathrm{H}_{2} \mathrm{O}$; this could be attributed to the occurrence of a bimolecular quenching induced by the formation of an $\mathrm{H}$ bond with the central amine nitrogen.

The water-insoluble NNNtos(Qui) does not show any fluorescence signal in organic solvents, probably because of an intramolecular quenching due to rotation of the tosyl moiety around the $\mathrm{N}-\mathrm{S}$ bond.

\section{Fluorescence Properties of the Complexes}

Both the complexes $\left[\mathrm{Zn}\{\mathrm{NNN}(\mathrm{Qui})\} \mathrm{Cl}_{2}\right]$ and $[\mathrm{Zn}$ $\left.\{\mathrm{NNNtos}(\mathrm{Qui})\} \mathrm{Cl}_{2}\right]$ are soluble and fluorescent in $\mathrm{H}_{2} \mathrm{O}$. Probably, metal coordination to the aliphatic nitrogen in $\left[\mathrm{Zn}\{\mathrm{NNN}(\mathrm{Qui})\} \mathrm{Cl}_{2}\right]$ prevents its interaction with the protic solvent; ${ }^{[44]}$ the fluorescence quantum yield, however, is very low $(\Phi<0.001)$. On the contrary, a relatively high quantum yield $\Phi$ is observed for $\left[\mathrm{Zn}\{\mathrm{NNNtos}(\mathrm{Qui})\} \mathrm{Cl}_{2}\right]$, both in $\mathrm{H}_{2} \mathrm{O}\left[\lambda^{\mathrm{max}}{ }_{\mathrm{em}}(\mathrm{nm})=440 ; \Phi=0.050 \pm 0.005\right]$ and $\mathrm{CH}_{3} \mathrm{CN}$ $\left[\lambda_{\mathrm{em}}^{\max }(\mathrm{nm})=375 ; \Phi=0.020 \pm 0.002\right]$. A plausible explanation for this behavior is that steric constraint due to metal- $\mathrm{N}$ chelation limits the rotational freedom of the tosyl group, thereby preventing the fluorescence quenching observed for the free ligand.

The fluorescent behavior of the ligand NNN(Qui) has also been studied with $\mathrm{Cd}^{2+}$. A mild increase (twofold) of the fluorescent signal at $\lambda_{\mathrm{em}}=520 \mathrm{~nm}$ has been observed for a $\mathrm{Cd} / \mathrm{NNN}$ (Qui) ratio of 2000/1. This is probably due to the high spin/orbit coupling constant of $\mathrm{Cd}^{2+}$. For the sake of completeness a Table summarizing the photochemical properties of several complexes bearing similar ligands and the related references is reported in the Supporting Information (Table 4SI).

\section{Conclusions}

From the present study it may be deduced that:

a) Bis-chelate complexes of the zinc triad with terdentate and potentially fluorescent ligands of the type NNN or NSN are easily obtained when perchlorate salts of the metals are used in the coordination reaction.

b) Monochelate complexes of the zinc triad with the above-mentioned ligands are easily obtained when chloride salts of the metals are used.

c) Among the X-ray determinations the structure of the complex $\left[\mathrm{Hg}\{\mathrm{NSN}(\mathrm{Qui})\} \mathrm{OClO}_{3}\right] \mathrm{ClO}_{4}$, which is quite unusual, bears witness to the flexibility in solution of this sort of ligand when coordinated to $\mathrm{d}^{10}$ metals.

d) The macroscopic and microscopic set of acid dissociation constants for the terdentate NSN and NNN ligands has been determined.

e) The fluorescence of the ligands and of the corresponding metal complexes has been studied. In the case of the fluorescent silent ligands NNN(Qui) and NNNtos(Qui) the corresponding complexes with $\mathrm{Zn}$ were shown to be fluorescent.

\section{Experimental Section}

Solvents and Reagents: $\mathrm{CH}_{3} \mathrm{CN}, \mathrm{CH}_{3} \mathrm{OH}$, and $\mathrm{H}_{2} \mathrm{SO}_{4}$ were commercial-grade chemicals and were used without further purification. $\mathrm{HCl}(0.1 \mathrm{~m})$ and $\mathrm{NaOH}(0.1 \mathrm{~m})$ were prepared by appropriate dilution of NORMEX solutions (Carlo Erba Reagents). $\mathrm{Hg}\left(\mathrm{ClO}_{4}\right)_{2}$. $6 \mathrm{H}_{2} \mathrm{O}, \mathrm{Cd}\left(\mathrm{ClO}_{4}\right)_{2} \cdot 6 \mathrm{H}_{2} \mathrm{O}$ (Alfa-Aesar), $\mathrm{Zn}\left(\mathrm{ClO}_{4}\right)_{2} \cdot 6 \mathrm{H}_{2} \mathrm{O}, \mathrm{AgNO}_{3}$, $\mathrm{HgCl}_{2}, \mathrm{CdCl}_{2} \cdot \mathrm{H}_{2} \mathrm{O}, \mathrm{ZnCl}_{2}$ (Sigma-Aldrich), and $\mathrm{CD}_{3} \mathrm{CN}$ and $\mathrm{CD}_{3} \mathrm{OD}$ were commercial-grade reagents and used without further purification.

IR, NMR, UV/Vis, and Fluorescence Measurements: IR and ${ }^{1} \mathrm{H}$ and ${ }^{13} \mathrm{C}\left\{{ }^{1} \mathrm{H}\right\}$ NMR spectra were recorded with a Perkin-Elmer Spectrum One spectrophotometer and a Bruker Avance 300 spectrometer, respectively. The proton and carbon assignment was performed by ${ }^{1} \mathrm{H}_{-}{ }^{13} \mathrm{C}-\mathrm{HMQC}$ and $\mathrm{HMBC}$ techniques in the case of the bischelate complexes $\left[\mathrm{ML}_{2}\right]\left(\mathrm{ClO}_{4}\right)_{2}[\mathrm{M}=\mathrm{Zn}, \mathrm{Cd}, \mathrm{Hg} ; \mathrm{L}=\mathrm{NSN}$ (Qui), $\mathrm{NNN}$ (Qui)]. The proton assignment for the chlorinated complexes $\left[\mathrm{MLCl}_{2}\right][\mathrm{M}=\mathrm{Zn}, \mathrm{Cd}, \mathrm{Hg}$; L = NSN(Qui), NNN(Qui)] and for all complexes with NNNtos(Qui) as ancillary ligand was achieved by ${ }^{1} \mathrm{H}-{ }^{1} \mathrm{H}-\mathrm{COSY}$ experiment because of their low solubility. UV/Vis spectra were taken with a Perkin-Elmer Lambda 40 spectrophotometer equipped with a Perkin-Elmer PTP6 (Peltier temperature programmer) apparatus. All fluorescence spectra were recorded with a Perkin-Elmer luminescence spectrometer LS $50(T=298 \mathrm{~K})$ and fluorescence quantum yields $\Phi_{\mathrm{X}}$ were measured relative to quinine sulfate in $\mathrm{H}_{2} \mathrm{SO}_{4}(0.5 \mathrm{M})$ as a standard and calculated according to the following formula: 


$$
\Phi_{X}=\Phi_{S T} \frac{S_{X}}{S_{S T}} \cdot \frac{A_{S T}}{A_{X}} \cdot \frac{n_{X}^{2}}{n_{S T}^{2}}
$$

where $S$ represents the area of the corrected emission fluorescence spectra $\left(\lambda_{\text {exc }}=320 \mathrm{~nm}\right), A$ is the optical density at $320 \mathrm{~nm}$, and $n$ the refractive index of the solvent used.

Synthesis of Ligands: The synthesis of the ligands NSN(Py), NSN(Qui), and NNNtos(Qui) was carried out according to the published procedure. ${ }^{[12]}$

8-I(Pyridylmethyl)aminol-quinoline $\mathbf{N N N ( Q u i ) : ~ T o ~ c o n c e n t r a t e d ~}$ $\mathrm{H}_{2} \mathrm{SO}_{4}$ (7.5 mL) 8- $N$-tosyl- $N$-(2-pyridylmethyl)quinoline [NNNtos(Qui)] (2.358 g, $6.05 \mathrm{mmol})$ was added and the solution was stirred for $2 \mathrm{~h}$ at $110^{\circ} \mathrm{C}$. To the resulting mixture a saturated aqueous solution of $\mathrm{NaCl}(10 \mathrm{~mL})$ and $\mathrm{NaOH}(6 \mathrm{M}, 60 \mathrm{~mL})$ was added. The neutral residue was extracted with $\mathrm{CH}_{2} \mathrm{Cl}_{2}$ and washed with a saturated aqueous solution of $\mathrm{NaCl}$. The organic phase was eventually dried under vacuum. The crude product was purified by flash chromatography through a silica column with a $1: 1 \mathrm{CH}_{2} \mathrm{Cl}_{2} / \mathrm{Et}_{2} \mathrm{O}$ mixture as eluent. Concentration under vacuum of the eluate yields $1.088 \mathrm{~g}(4.62 \mathrm{mmol})$ of the title compound as a yellow/green oil. Yield $76 \%$. ${ }^{1} \mathrm{H}$ NMR $\left(\mathrm{CD}_{3} \mathrm{CN}, T=298 \mathrm{~K}\right): \delta=$ aminomethyl protons, $4.66\left(\mathrm{~d}, J_{\mathrm{CH} 2-\mathrm{NH}}=5.92 \mathrm{~Hz}, 2 \mathrm{H}\right.$, pyr- $\left.\mathrm{CH}_{2} \mathrm{~N}\right)$, amine protons 7.25 (br. s, $1 \mathrm{H}$, pyr- $\mathrm{NH}$ ), pyridine and quinoline protons 6.67 (dd, $\left.1 \mathrm{H}, 7-\mathrm{H}_{\text {qui }}\right), 7.11\left(\mathrm{dd}, J=7.93 \mathrm{~Hz}\right.$ and $J=1.15 \mathrm{~Hz}, 1 \mathrm{H}, 5-\mathrm{H}_{\text {qui }}$ ), $7.27\left(\mathrm{dd}, J=4.83 \mathrm{~Hz}, 1 \mathrm{H}, 3^{\prime}-\mathrm{H}_{\mathrm{pyr}}\right), 7.36\left(\mathrm{t}, 1 \mathrm{H}, 6-\mathrm{H}_{\mathrm{qui}}\right), 7.41(\mathrm{~d}$, $\left.1 \mathrm{H}, 5^{\prime}-\mathrm{H}_{\mathrm{pyr}}\right), 7.48\left(\mathrm{dd}, 1 \mathrm{H}, 3-\mathrm{H}_{\text {qui }}\right), 7.72(\mathrm{td}, J=8.00$ and $J=$ $\left.1.75 \mathrm{~Hz}, 1 \mathrm{H}, 4^{\prime}-\mathrm{H}_{\mathrm{pyr}}\right), 8.18(\mathrm{dd}, J=8.33$ and $J=1.75 \mathrm{~Hz}, 1 \mathrm{H}, 4-$ $\left.\mathrm{H}_{\text {qui }}\right), 8.62\left(\mathrm{~d}, 1 \mathrm{H}, 2^{\prime}-\mathrm{H}_{\mathrm{pyr}}\right), 8.79(\mathrm{dd}, J=4.17 \mathrm{~Hz}, 1 \mathrm{H}, 2-$ $\left.\mathrm{H}_{\text {qui }}\right)$ ppm. ${ }^{13} \mathrm{C} \mathrm{NMR}\left(\mathrm{CD}_{3} \mathrm{CN}, T=298 \mathrm{~K}\right): \delta=$ thiomethyl carbon, $48.03\left(\right.$ pyr $\left.-\mathrm{CH}_{2} \mathrm{~N}\right)$, pyridine $\mathrm{C}$ atoms $121.34,121.59,122.04(\mathrm{C}-$ $5^{\prime}{ }_{\text {pyp }}$ C-3 ${ }_{\text {pyp }}^{\prime}$ C-3 $\left.{ }_{\text {qui }}\right), 136.54$ (C-4 $\left.{ }_{\text {pyr }}\right), 149.00$ (C-2' $\left.{ }_{\text {pyr }}\right), 158.50$ (C$\left.6^{\prime}{ }_{\text {pyr }}\right)$, quinoline $\mathrm{C}$ atoms 104.91 (C-5 qui $), 113.90\left(\mathrm{C}-7_{\text {qui }}\right), 127.63$ $\left(\mathrm{C}-6_{\text {qui }}\right), 128.56\left(\mathrm{C}-4 \mathrm{a}_{\text {qui }}\right), 138.05\left(\mathrm{C}-8_{\text {qui }}\right), 138.83\left(\mathrm{C}-4_{\text {qui }}\right), 144.36$ $\left(\mathrm{C}-8 \mathrm{a}_{\text {qui }}\right), 147.14\left(\mathrm{C}-2_{\text {qui }}\right)$ ppm. ${ }^{1} \mathrm{H} \mathrm{NMR}\left(\mathrm{CDCl}_{3}, T=298 \mathrm{~K}\right): \delta=$ aminomethyl protons, $4.73\left(\mathrm{~d}, J=5.8 \mathrm{~Hz}, 2 \mathrm{H}\right.$, pyr- $\left.\mathrm{CH}_{2} \mathrm{~N}\right)$, amine protons 7.03 (br. s, $1 \mathrm{H}$, pyr- $\mathrm{NH}$ ), pyridine and quinoline protons $7.09\left(\mathrm{dd}, J=8.1\right.$ and $\left.1.1 \mathrm{~Hz}, 1 \mathrm{H}, 5-\mathrm{H}_{\text {qui }}\right), 7.20(\mathrm{dd}, J=4.7$ and $=$ $\left.7.6 \mathrm{~Hz}, 2 \mathrm{H}, 3^{\prime}-\mathrm{H}_{\mathrm{pyr}}\right), 7.34\left(\mathrm{t}, J=7.5 \mathrm{~Hz}, 1 \mathrm{H}, 6-\mathrm{H}_{\text {qui }}\right), 7.41(\mathrm{~m}, 2$ $\left.\mathrm{H}, 3-\mathrm{H}_{\text {qui }}, 5^{\prime}-\mathrm{H}_{\text {pyr }}\right), 7.63\left(\mathrm{td}, J=7.6\right.$ and $\left.1.8 \mathrm{~Hz}, 1 \mathrm{H}, 4^{\prime}-\mathrm{H}_{\mathrm{pyr}}\right), 8.09$ (dd, $J=8.3$ and $\left.1.7 \mathrm{~Hz}, 1 \mathrm{H}, 4-\mathrm{H}_{\text {qui }}\right), 8.65\left(\mathrm{~d}, 1 \mathrm{H}, 2^{\prime}-\mathrm{H}_{\text {pyr }}\right.$ ), 8.79 (dd, $\left.J=4.2 \mathrm{~Hz}, 1 \mathrm{H}, 2-\mathrm{H}_{\text {qui }}\right) \mathrm{ppm} .{ }^{13} \mathrm{C} \mathrm{NMR}\left(\mathrm{CDCl}_{3}, T=298 \mathrm{~K}\right)$ : $\delta=$ thiomethyl carbon, $49.1\left(\right.$ pyr- $\left.\mathrm{CH}_{2} \mathrm{~N}\right)$, pyridine $\mathrm{C}$ atoms 121.0 , 121.4, 121.9 (C-5 $\left.{ }_{\text {pyr }}, \mathrm{C}-3^{\prime}{ }_{\text {pyp }} \mathrm{C}-3_{\text {qui }}\right), 136.6\left(\mathrm{C}-4^{\prime}{ }_{\text {pyr }}\right), 149.3$ (C$\left.2^{\prime}{ }_{\text {pyr }}\right), 158.9\left(\mathrm{C}-6^{\prime}{ }_{\text {pyr }}\right)$, quinoline $\mathrm{C}$ atoms $105.2\left(\mathrm{C}-5_{\text {qui }}\right), 114.3(\mathrm{C}-$ $\left.7_{\text {qui }}\right), 127.6\left(\mathrm{C}-6_{\text {qui }}\right), 128.6\left(\mathrm{C}-10_{\text {qui }}\right), 138.3\left(\mathrm{C}-4_{\text {qui }}\right), 144.3$ (C-9 qui $)$, 147.0 (C-2 qui $)$ ppm.

\section{Synthesis of Bis-Chelate Complexes}

$\left[\mathbf{H g}\left[\mathbf{N N N}(\text { Qui) }]_{2}\right]\left(\mathbf{C l O}_{4}\right)_{2}\right.$ : A solution of $\mathrm{Hg}\left(\mathrm{ClO}_{4}\right)_{2} \cdot 6 \mathrm{H}_{2} \mathrm{O}(0.0861 \mathrm{~g}$, $0.18 \mathrm{mmol})$ in acetonitrile $(4 \mathrm{~mL})$ was added slowly to a stirred solution of $\mathrm{NNN}$ (Qui) $(0.09 \mathrm{~g}, 0.38 \mathrm{mmol})$ in acetonitrile $(2 \mathrm{~mL})$. The resulting solution was diluted $1: 1$ with toluene at $0{ }^{\circ} \mathrm{C}$. The solution was concentrated under reduced pressure and the complex precipitated. The complex was filtered off, washed with toluene, pentane, and dried under vacuum. Cream microcrystals were obtained $(0.1224 \mathrm{~g}, 0.14 \mathrm{mmol})$. Yield $80 \%$. IR $(\mathrm{KBr}): \tilde{v}=v_{\mathrm{N}-\mathrm{H}}$ 3289.4, $v_{\mathrm{C}-\mathrm{H}}$ 3048.0, 2920.7, $v_{\mathrm{C}=\mathrm{N}}$ 1613.4, $v_{\mathrm{C}=\mathrm{C}} 1512.8,1445.8$, $v_{\mathrm{ClO} 4}{ }^{-} 1090.5 \mathrm{~cm}^{-1} .{ }^{1} \mathrm{H} \mathrm{NMR}\left(\mathrm{CD}_{3} \mathrm{CN}, T=298 \mathrm{~K}\right): \delta=$ aminomethyl protons, 4.69 (s, $4 \mathrm{H}$, pyr- $N-\mathrm{CH}_{2}$ ), amine protons, 6.14 (br. s, $2 \mathrm{H}$, pyr-NH), pyridine and quinoline protons 7.39 (d, $J=$ 8.2 and $\left.4.5 \mathrm{~Hz}, 2 \mathrm{H}, 3-\mathrm{H}_{\text {qui }}\right), 7.58\left(\mathrm{~m}, 6 \mathrm{H}, 6-\mathrm{H}_{\text {qui }}, 7-\mathrm{H}_{\text {qui }}, 3^{\prime}-\mathrm{H}_{\text {pyr }}\right)$, 7.69 (dd, $J=7.35$ and $\left.2.3 \mathrm{~Hz}, 2 \mathrm{H}, 5-\mathrm{H}_{\text {qui }}\right), 7.75(\mathrm{~d}, J=7.9 \mathrm{~Hz}, 2$
$\left.\mathrm{H}, 5^{\prime}-\mathrm{H}_{\mathrm{pyr}}\right), 8.14\left(\mathrm{td}, J=7.7\right.$ and $\left.1.7 \mathrm{~Hz}, 2 \mathrm{H}, 4^{\prime}-\mathrm{H}_{\mathrm{pyr}}\right), 8.25(\mathrm{~m}, 4$ $\left.\mathrm{H}, 4-\mathrm{H}_{\text {qui }}, 2-\mathrm{H}_{\text {qui }}\right), 8.42\left(\mathrm{~d}, J=4.8 \mathrm{~Hz}, 2 \mathrm{H}, 2^{\prime}-\mathrm{H}_{\text {pyr }}\right) \mathrm{ppm} .{ }^{13} \mathrm{C}$ NMR $\left(\mathrm{CD}_{3} \mathrm{CN}, T=298 \mathrm{~K}\right): \delta=$ aminomethyl $\mathrm{C}$ atoms, 51.7 (pyr$\left.\mathrm{N}-\mathrm{CH}_{2}\right)$, quinoline $\mathrm{C}$ atoms $122.0\left(\mathrm{C}-3_{\text {qui }}\right), 125.2,125.8$ (C-5 qui, C$\left.7_{\text {qui }}\right), 127.39$ (C-6 qui $), 128.2$ (C-8 qui $), 128.8$ (C-10 qui $), 138.9$ (C-4 qui $\left._{\text {qu }}\right)$, 139.0 (C-9 qui), 150.3 (C-2 qui ; pyridine $\mathrm{C}$ atoms 122.4 (C-3' ${ }_{\text {pyr }}$ ), 125.8 (C-5 $\left.{ }_{\text {pyr }}\right), 141.2\left(\mathrm{C}-4^{\prime}{ }_{\text {pyr }}\right), 149.1$ (C-2 $\left.{ }_{\text {pyr }}\right), 154.6$ (C-6 $\left.{ }^{\prime}{ }_{\text {pyr }}\right)$ ppm. $\mathrm{C}_{30} \mathrm{H}_{26} \mathrm{Cl}_{2} \mathrm{HgN}_{6} \mathrm{O}_{8}$ : calcd. C 41.41, H 3.01, N 9.66; found C 41.25, H 2.97, N 9.51.

The following complexes were synthesized in an analogous way using the appropriate perchlorate salts.

[Cd $\left\{\mathbf{N N N}(\text { Qui) }\}_{2}\right]\left(\mathbf{C l O}_{4}\right)_{2}$ : Yield $85 \%$ (white microcrystals). IR $(\mathrm{KBr}): \tilde{v}=v_{\mathrm{N}-\mathrm{H}} 3251.4, v_{\mathrm{C}-\mathrm{H}} 3078.6,2931.4, v_{\mathrm{C}=\mathrm{N}}$ 1613.3, $v_{\mathrm{C}=\mathrm{C}}$ 1511.0, 1440.6, $v_{\mathrm{ClO} 4}{ }^{-} 1107.9 \mathrm{~cm}^{-1}$. ${ }^{1} \mathrm{H} \mathrm{NMR}\left(\mathrm{CD}_{3} \mathrm{CN}, T=298 \mathrm{~K}\right)$ : $\delta=$ aminomethyl protons, $4.61\left(\mathrm{~s}, 4 \mathrm{H}\right.$, pyr- $\left.-\mathrm{N}_{-} \mathrm{CH}_{2}\right)$, amine protons, 5.70 (br. s, $2 \mathrm{H}$, pyr-NH), pyridine and quinoline protons $7.48(\mathrm{~m}$, $\left.4 \mathrm{H}, 3-\mathrm{H}_{\text {qui }}, 3^{\prime}-\mathrm{H}_{\mathrm{pyr}}\right), 7.65\left(\mathrm{~d}, J=7.7 \mathrm{~Hz}, 2 \mathrm{H}, 5^{\prime}-\mathrm{H}_{\mathrm{pyr}}\right), 7.72(\mathrm{t}, 2$ $\left.\mathrm{H}, 6-\mathrm{H}_{\text {qui }}\right), 7.85\left(\mathrm{dd}, J=6.2 \mathrm{~Hz}, 2 \mathrm{H}, 7-\mathrm{H}_{\text {qui }}\right), 7.90(\mathrm{dd}, J=8.3$ and $\left.1.1 \mathrm{~Hz}, 2 \mathrm{H}, 5-\mathrm{H}_{\text {qui }}\right), 8.08\left(\mathrm{td}, J=7.7 \mathrm{~Hz}, 2 \mathrm{H}, 4^{\prime}-\mathrm{H}_{\mathrm{pyr}}\right), 8.20$ (dd, $\left.J=4.6 \mathrm{~Hz}, 2 \mathrm{H}, 4-\mathrm{H}_{\text {qui }}\right), 8.28\left(\mathrm{~d}, J=4.7 \mathrm{~Hz}, 2 \mathrm{H}, 2^{\prime}-\mathrm{H}_{\mathrm{pyr}}\right.$ ), $8.45\left(\mathrm{dd}, J=8.3\right.$ and $\left.1.6 \mathrm{~Hz}, 2 \mathrm{H}, 2-\mathrm{H}_{\text {qui }}\right) \mathrm{ppm} .{ }^{13} \mathrm{C} \mathrm{NMR}\left(\mathrm{CD}_{3} \mathrm{CN}\right.$, $T=298 \mathrm{~K}): \delta=$ aminomethyl $\mathrm{C}$ atoms, $53.9\left(\right.$ pyr- $\left.\mathrm{N}-\mathrm{CH}_{2}\right)$, quinoline $\mathrm{C}$ atoms $122.6\left(\mathrm{C}-3_{\text {qui }}\right), 124.9$ (C-7 qui $), 126.4\left(\mathrm{C}-5_{\text {qui }}\right), 127.7$ (C$\left.6_{\text {qui }}\right), 129.2\left(\mathrm{C}-10_{\text {qui }}\right), 139.6$ (C-2 $\left.2_{\text {qui }}\right), 139.7$ (C-8 qui $), 140.5$ (C-9 qui $)$, $150.3\left(\mathrm{C}-4_{\text {qui }}\right)$; pyridine $\mathrm{C}$ atoms $124.7\left(\mathrm{C}-5^{\prime}{ }_{\text {pyr }}\right), 125.0\left(\mathrm{C}-3^{\prime}{ }_{\text {pyr }}\right)$, 140.6 (C-4 $\left.{ }_{\text {pyr }}^{\prime}\right), 148.5$ (C-2 $\left.{ }_{\text {pyr }}\right), 155.8\left(\mathrm{C}-6^{\prime}{ }_{\text {pyr }}\right) . \mathrm{C}_{30} \mathrm{H}_{26} \mathrm{CdCl}_{2} \mathrm{~N}_{6} \mathrm{O}_{8}$ : calcd. C 46.08, H 3.35, N 10.75; found C 46.15, H 3.28, N 10.62.

$\left[\mathbf{Z n}\{\mathbf{N N N}(\mathbf{Q u i})\}_{2}\right]\left(\mathrm{ClO}_{4}\right)_{2}$ : The precipitation of the complex was induced by addition of toluene to the reaction mixture. Yield $94 \%$ (pale yellow microcrystals). IR $(\mathrm{KBr}): \tilde{\mathrm{v}}=\mathrm{v}_{\mathrm{N}-\mathrm{H}}$ 3238.6, $v_{\mathrm{C}-\mathrm{H}}$ $3085.0, \quad 2937.8, \quad v_{\mathrm{C}=\mathrm{N}} \quad 1619.7, \quad v_{\mathrm{C}=\mathrm{C}} \quad 1517.4, \quad 1440.6, \quad v_{\mathrm{ClO} 4}{ }^{-}$ $1101.5 \mathrm{~cm}^{-1}$. ${ }^{1} \mathrm{H}$ NMR $\left(\mathrm{CD}_{3} \mathrm{CN}, T=298 \mathrm{~K}\right): \delta=$ aminomethyl protons, 4.70 (s, $4 \mathrm{H}$, pyr- $\mathrm{N}-\mathrm{CH}_{2}$ ), amine protons, 6.01 (br. s, $2 \mathrm{H}$, pyr-NH), pyridine and quinoline protons $7.52\left(\mathrm{~m}, 6 \mathrm{H}, 3-\mathrm{H}_{\text {qui }}, 3^{\prime}\right.$ $\mathrm{H}_{\text {pyp }}, 5^{\prime}-\mathrm{H}_{\text {pyr }}$ ), 7.69 (t, $2 \mathrm{H}, 6-\mathrm{H}_{\text {qui }}$ ), 7.81 (br. d, $J=8.1 \mathrm{~Hz}, 2 \mathrm{H}, 7-$ $\mathrm{H}_{\text {qui }}$ ), 7.85 (br. d, $J=8.4 \mathrm{~Hz}, 2 \mathrm{H}, 5-\mathrm{H}_{\text {qui }}$ ), 8.00 (td, $J=7.8$ and $\left.1.7 \mathrm{~Hz}, 2 \mathrm{H}, 4^{\prime}-\mathrm{H}_{\mathrm{pyr}}\right), 8.43$ (d, $J=8.4 \mathrm{~Hz}, 2 \mathrm{H}, 4-\mathrm{H}_{\text {qui }}$ ), 8.49 (br. d, $J=3.7 \mathrm{~Hz}, 2 \mathrm{H}, 2^{\prime}-\mathrm{H}_{\text {pyr }}$ ), 8.45 (br. d, $J=5.1 \mathrm{~Hz}, 2 \mathrm{H}, 2-\mathrm{H}_{\text {qui }}$ ) ppm. ${ }^{13} \mathrm{C}$ NMR $\left(\mathrm{CD}_{3} \mathrm{CN}, T=298 \mathrm{~K}\right): \delta=$ aminomethyl $\mathrm{C}$ atoms, 53.9 (pyr-N-CH$\left.{ }_{2}\right)$, quinoline $\mathrm{C}$ atoms $122.6\left(\mathrm{C}-3_{\text {qui }}\right), 125.9\left(\mathrm{C}-7_{\text {qui }}\right)$, 126.9 (C-5 qui $), 128.0$ (C-6 qui $), 129.0$ (C-10 qui $), 139.6$ (C-4 qui $), 139.6$ $\left(\mathrm{C}-8_{\text {qui }}\right), 140.6$ (C-9 qui $), 149.5$ (C-2 qui $)$; pyridine $\mathrm{C}$ atoms 124.9 , 125.0 (C-5 $\left.{ }_{\text {pyr }}, \mathrm{C}-3^{\prime}{ }_{\text {pyr }}\right), 140.8$ (C-4 ${ }_{\text {pyr }}$ ), $147.7\left(\mathrm{C}-2^{\prime}{ }_{\text {pyr }}\right), 155.2(\mathrm{C}-$ $6^{\prime}{ }_{\text {pyr }}$ ) ppm. $\mathrm{C}_{30} \mathrm{H}_{26} \mathrm{Cl}_{2} \mathrm{~N}_{6} \mathrm{O}_{8} \mathrm{Zn}$ : calcd. C 49.03, H 3.57, N 11.44; found C 48.98, H 3.67, N 11.61.

[Hg\{NSN(Qui) $\left.\}_{2}\right]\left(\mathrm{ClO}_{4}\right)_{2}$ : A solution $(10 \mathrm{~mL})$ of $\mathrm{Hg}\left(\mathrm{ClO}_{4}\right)_{2} \cdot 6 \mathrm{H}_{2} \mathrm{O}$ $(0.2447 \mathrm{~g}, 0.5 \mathrm{mmol})$ in methanol was added slowly to a stirred solution of NSN(Qui) $(0.2650 \mathrm{~g}, 1.05 \mathrm{mmol})$ in methanol $(20 \mathrm{~mL})$. Acetonitrile was then added $(30 \mathrm{~mL})$. Volume reduction induces the precipitation of the complex which was filtered off, washed with toluene, $n$-hexane and dried under vacuum. White microcrystals were obtained $(0.400 \mathrm{~g}, 0.44 \mathrm{mmol})$. Yield $88.5 \%$. IR $(\mathrm{KBr}): \tilde{v}=$ $v_{\mathrm{N}-\mathrm{H}}$ 3251.4, $v_{\mathrm{C}-\mathrm{H}}$ 3078.6, 2931.4, $v_{\mathrm{C}=\mathrm{N}}$ 1613.3, $v_{\mathrm{C}=\mathrm{C}}$ 1511.0, 1440.6, $v_{\mathrm{ClO} 4}^{-} 1107.9 \mathrm{~cm}^{-1} .{ }^{1} \mathrm{H}$ NMR $\left(\mathrm{CD}_{3} \mathrm{CN}, T=298 \mathrm{~K}\right): \delta=$ methylthio protons, 4.77 (s, $4 \mathrm{H}$, pyr-S- $\left.\mathrm{CH}_{2}\right)$, pyridine and quinoline protons $7.35\left(\mathrm{t}, 2 \mathrm{H}, 3^{\prime}-\mathrm{H}_{\mathrm{pyr}}\right), 7.46\left(\mathrm{~d}, J=7.7 \mathrm{~Hz}, 2 \mathrm{H}, 5^{\prime}-\right.$ $\mathrm{H}_{\text {pyr }}$ ), 7.70 (dd, $J=4.40$ and $\left.7.7 \mathrm{~Hz}, 2 \mathrm{H}, 3-\mathrm{H}_{\text {qui }}\right), 7.86(\mathrm{~m}, 4 \mathrm{H}, 6-$ $\left.\mathrm{H}_{\text {qui }}, 4^{\prime}-\mathrm{H}_{\mathrm{pyr}}\right), 8.21\left(\mathrm{~d}, J=8.1 \mathrm{~Hz}, 2 \mathrm{H}, 5-\mathrm{H}_{\text {qui }}\right), 8.38(\mathrm{~d}, J=5.1 \mathrm{~Hz}$, $\left.2 \mathrm{H}, 2^{\prime}-\mathrm{H}_{\mathrm{pyr}}\right), 8.55\left(\mathrm{~d}, J=6.6 \mathrm{~Hz}, 2 \mathrm{H}, 7-\mathrm{H}_{\text {qui }}\right), 8.61(\mathrm{dd}, J=7.7$ and $\left.1.5 \mathrm{~Hz}, 2 \mathrm{H}, 4-\mathrm{H}_{\text {qui }}\right), 8.79\left(\mathrm{~d}, J=4.4 \mathrm{~Hz}, 2 \mathrm{H}, 2-\mathrm{H}_{\text {qui }}\right) \mathrm{ppm}$. ${ }^{13} \mathrm{C}$ NMR $\left(\mathrm{CD}_{3} \mathrm{CN}, T=298 \mathrm{~K}\right): \delta=$ methylthio $\mathrm{C}$ atoms, 42.4 (pyr-S- $\left.\mathrm{CH}_{2}\right)$, quinoline $\mathrm{C}$ atoms $122.9\left(\mathrm{C}-3_{\text {qui }}\right), 125.1\left(\mathrm{C}-10_{\text {qui }}\right)$, 
$128.1\left(\mathrm{C}-6_{\text {qui }}\right), 130.1$ (C-8 qui $), 132.5\left(\mathrm{C}-5_{\text {qui }}\right), 139.3\left(\mathrm{C}-7_{\text {qui }}\right), 141.1$ $\left(\mathrm{C}-4_{\text {qui }}\right), 142.1$ (C-9 qui), $152.0\left(\mathrm{C}-2_{\text {qui }}\right)$; pyridine $\mathrm{C}$ atoms 124.9 (C$\left.3^{\prime}{ }_{\text {pyr }}\right), 126.9$ (C-5 ${ }_{\text {pyr }}$ ), 140.4 (C-4' $\left.{ }_{\text {pyr }}\right), 148.9$ (C-2 ${ }_{\text {pyr }}$ ), 151.4 (C$6^{\prime}{ }_{\text {pyr }}$ ) ppm. $\mathrm{C}_{30} \mathrm{H}_{24} \mathrm{Cl}_{2} \mathrm{HgN}_{4} \mathrm{O}_{8} \mathrm{~S}_{2}$ : calcd. C 39.85; H 2.68, N 6.20; found $\mathrm{C} 40.02, \mathrm{H} 2.67, \mathrm{~N} 6.41$.

The following complexes were synthesized in an analogous way using the appropriate ligand and perchlorate salts.

$\left[\mathbf{C d}\{\mathrm{NSN}(\mathbf{Q u i})\}_{2}\right]\left(\mathrm{ClO}_{4}\right)_{2}$ : The complex precipitated soon after addition of $\mathrm{Cd}\left(\mathrm{ClO}_{4}\right)_{2} \cdot 6 \mathrm{H}_{2} \mathrm{O}$ and no reduction of the volume was necessary. Yield 97\% (white microcrystals). IR $(\mathrm{KBr}): \tilde{v}={ }_{\mathrm{C}-\mathrm{H}}$ 3073.7, 2970.8, 2919.3 $v_{\mathrm{C}=\mathrm{N}}$ 1606.6, $v_{\mathrm{C}=\mathrm{C}} 1497.4,1446.0, v_{\mathrm{ClO} 4}$ $1092.1 \mathrm{~cm}^{-1} .{ }^{1} \mathrm{H}$ NMR $\left(\mathrm{CD}_{3} \mathrm{CN}, T=298 \mathrm{~K}\right): \delta=$ methylthio protons, $4.74\left(\mathrm{~s}, 4 \mathrm{H}\right.$, pyr-S- $\left.\mathrm{CH}_{2}\right)$, pyridine and quinoline protons 7.35 (t, $\left.2 \mathrm{H}, 3^{\prime}-\mathrm{H}_{\mathrm{pyr}}\right), 7.53\left(\mathrm{~d}, J=7.7 \mathrm{~Hz}, 2 \mathrm{H}, 5^{\prime}-\mathrm{H}_{\mathrm{pyr}}\right), 7.70(\mathrm{dd}, J=$ 4.7 and $\left.8.3 \mathrm{~Hz}, 2 \mathrm{H}, 3-\mathrm{H}_{\text {qui }}\right), 7.88\left(\mathrm{~m}, 4 \mathrm{H}, 6-\mathrm{H}_{\text {qui }}, 4^{\prime}-\mathrm{H}_{\mathrm{pyr}}\right), 8.24$ $\left(\mathrm{d}, J=8.4 \mathrm{~Hz}, 2 \mathrm{H}, 5-\mathrm{H}_{\mathrm{qui}}\right), 8.32\left(\mathrm{~d}, J=5.1 \mathrm{~Hz}, 2 \mathrm{H}, 2^{\prime}-\mathrm{H}_{\mathrm{pyr}}\right), 8.55$ $\left(\mathrm{d}, J=7.3 \mathrm{~Hz}, 2 \mathrm{H}, 7-\mathrm{H}_{\text {qui }}\right), 8.66\left(\mathrm{~d}, J=8.4 \mathrm{~Hz}, 2 \mathrm{H}, 4-\mathrm{H}_{\text {qui }}\right), 8.77$ (dd, $J=4.7$ and $\left.1.8 \mathrm{~Hz}, 2 \mathrm{H}, 2-\mathrm{H}_{\text {qui }}\right) \mathrm{ppm} .{ }^{13} \mathrm{C} \mathrm{NMR}\left(\mathrm{CD}_{3} \mathrm{CN}, T\right.$ $=298 \mathrm{~K}): \delta=$ methylthio $\mathrm{C}$ atoms, $42.3\left(\right.$ pyr-S- $\left.\mathrm{CH}_{2}\right)$, quinoline $\mathrm{C}$ atoms $122.5\left(\mathrm{C}-3_{\text {qui }}\right), 125.89\left(\mathrm{C}-10_{\text {qui }}\right), 128.1\left(\mathrm{C}-6_{\text {qui }}\right), 130.0(\mathrm{C}-$ $8_{\text {qui }}$, 130.0 (C-5 qui $), 139.0$ (C-7 qui $), 140.5$ (C-4 qui $), 143.5$ (C-9 qui $)$, 152.5 (C-2 qui); pyridine $\mathrm{C}$ atoms 124.8 (C-3' $\left.{ }_{\text {pyr }}\right), 126.4\left(\mathrm{C}-5^{\prime}{ }_{\text {pyr }}\right)$, $140.5 \quad\left(\mathrm{C}-4^{\prime}{ }_{\mathrm{pyr}}\right), \quad 149.1 \quad\left(\mathrm{C}-2^{\prime}{ }_{\mathrm{pyr}}\right), \quad 153.0 \quad\left(\mathrm{C}-6^{\prime}{ }_{\mathrm{pyr}}\right) \mathrm{ppm}$. $\mathrm{C}_{30} \mathrm{H}_{24} \mathrm{CdCl}_{2} \mathrm{~N}_{4} \mathrm{O}_{8} \mathrm{~S}_{2}$ : calcd. C 44.16, $\mathrm{H}$ 2.96, N 6.87; found $\mathrm{C}$ 44.12, H 2.89, N 6.81 .

[Zn\{NSN(Qui) $\left.\}_{2}\right]\left(\mathbf{C l O}_{4}\right)_{2}$ : Yield $91 \%$ (white microcrystals). IR $(\mathrm{KBr}): \tilde{v}=v_{\mathrm{C}-\mathrm{H}} 3072.0,2993.1,2933.8, v_{\mathrm{C}=\mathrm{N}} 1604.4, v_{\mathrm{C}=\mathrm{C}} 1505.7$, $1485.9,1446.4, v_{\mathrm{ClO}^{-}}{ }^{-} 1091.0 \mathrm{~cm}^{-1} .{ }^{1} \mathrm{H} \mathrm{NMR}\left(\mathrm{CD}_{3} \mathrm{CN}, T=298 \mathrm{~K}\right)$ : $\delta=$ methylthio protons, $4.74\left(\mathrm{~s}, 4 \mathrm{H}\right.$, pyr-S- $\left.\mathrm{CH}_{2}\right)$, pyridine and quinoline protons $7.38\left(\mathrm{~m}, 4 \mathrm{H}, 3^{\prime}-\mathrm{H}_{\mathrm{pyr}}, 5^{\prime}-\mathrm{H}_{\mathrm{pyr}}\right), 7.70(\mathrm{dd}, J=4.8$ and $\left.8.4 \mathrm{~Hz}, 2 \mathrm{H}, 3-\mathrm{H}_{\text {qui }}\right), 7.81\left(\mathrm{td}, J=7.7 \mathrm{~Hz}, 2 \mathrm{H}, 4^{\prime}-\mathrm{H}_{\mathrm{pyr}}\right), 7.89$ (t, $\left.J=7.9 \mathrm{~Hz}, 2 \mathrm{H}, 6-\mathrm{H}_{\text {qui }}\right), 8.23\left(\mathrm{~d}, 2 \mathrm{H}, 5-\mathrm{H}_{\text {qui }}\right), 8.62\left(\mathrm{~m}, 6 \mathrm{H}, 2^{\prime}-\right.$ $\left.\mathrm{H}_{\text {pyr }}, 4-\mathrm{H}_{\text {qui }}, 7-\mathrm{H}_{\text {qui }}\right), 8.94\left(\mathrm{~d}, J=4.8 \mathrm{~Hz}, 2 \mathrm{H}, 2-\mathrm{H}_{\text {qui }}\right) \mathrm{ppm} .{ }^{13} \mathrm{C}$ NMR $\left(\mathrm{CD}_{3} \mathrm{CN}, T=298 \mathrm{~K}\right.$ ): $\delta=$ methylthio $\mathrm{C}$ atoms, 42.6 (pyr-S$\left.\mathrm{CH}_{2}\right)$, quinoline $\mathrm{C}$ atoms $123.3\left(\mathrm{C}-3_{\text {qui }}\right), 128.5\left(\mathrm{C}-6_{\text {qui }}\right), 129.7(\mathrm{C}-$ $\left.8_{\text {qui }}\right), 132.2$ (C-5 qui $), 139.4$ (C-7 qui $), 141.2$ (C-4 qui $), 143.3$ (C-9 $\left.9_{\text {qui }}\right)$, 151.1 (C-2 qui); pyridine $\mathrm{C}$ atoms 125.1 (C-3' $\left.{ }_{\text {pyr }}\right), 126.3\left(\mathrm{C}-5^{\prime}{ }_{\text {pyr }}\right)$, $140.4 \quad\left(\mathrm{C}-4^{\prime}{ }_{\text {pyr }}\right), \quad 147.4 \quad\left(\mathrm{C}-2^{\prime}{ }_{\text {pyr }}\right), \quad 152.3 \quad\left(\mathrm{C}-6^{\prime}{ }_{\text {pyr }}\right)$ ppm. $\mathrm{C}_{30} \mathrm{H}_{24} \mathrm{Cl}_{2} \mathrm{~N}_{4} \mathrm{O}_{8} \mathrm{~S}_{2} \mathrm{Zn}$ : calcd. C 46.86, H. 3.15, N 7.29; found $\mathrm{C}$ 46.72, H 3.21, N 7.31.

$\left[\mathbf{H g}\{\mathbf{N N N t o s}(\mathbf{Q u i})\}_{2}\right]\left(\mathrm{ClO}_{4}\right)_{2}$ : The precipitation of the complex was obtained by lowering the temperature $\left(0{ }^{\circ} \mathrm{C}\right)$. Yield $75 \%$ (white microcrystals). IR (KBr): $\tilde{v}=v_{\mathrm{C}-\mathrm{H}} 3099.3,3061.0,2933.2,2862.9$, $v_{\mathrm{C}=\mathrm{N}} 1604.2, v_{\mathrm{C}=\mathrm{C}} 1508.4,1457.3, v_{\mathrm{ClO} 4}{ }^{-} 1093.1 \mathrm{~cm}^{-1} .{ }^{1} \mathrm{H} \mathrm{NMR}$ $\left(\mathrm{CD}_{3} \mathrm{CN}, T=233 \mathrm{~K}\right): \delta=$ methyl protons, $2.56\left(\mathrm{~s}, 3 \mathrm{H}, \mathrm{CH}_{3}\right)$, aminomethyl protons $4.93,5.79$ (AB system, $J=14.3$ and $4.8 \mathrm{~Hz}$, $J^{3}{ }_{\mathrm{H}-\mathrm{Hg}}=8.1 \mathrm{~Hz}, 2 \mathrm{H}$, pyr-N-CH ), pyridine, quinoline, and aromatic protons $7.26\left(\mathrm{~m}, J=6.7 \mathrm{~Hz}, 2 \mathrm{H}, 5-\mathrm{H}_{\text {qui }}\right), 7.55\left(\mathrm{~m}, 7 \mathrm{H}, 3^{\prime}\right.$ $\left.\mathrm{H}_{\text {pyr }}, 5^{\prime}-\mathrm{H}_{\text {pyr }}, 6-\mathrm{H}_{\text {qui }}, \mathrm{H}_{\mathrm{ar}}\right), 8.00\left(\mathrm{~m}, 2 \mathrm{H}, 4^{\prime}-\mathrm{H}_{\text {pyr }}, 3-\mathrm{H}_{\mathrm{qui}}\right), 8.23(\mathrm{~d}$, $\left.J=7.3 \mathrm{~Hz}, 1 \mathrm{H}, 7-\mathrm{H}_{\text {qui }}\right), 8.72\left(\mathrm{~d}, J=4.8 \mathrm{~Hz}, 1 \mathrm{H}, 2^{\prime}-\mathrm{H}_{\text {pyr }}\right), 8.79$ $\left(\mathrm{d}, J=8.4 \mathrm{~Hz}, 1 \mathrm{H}, 4-\mathrm{H}_{\text {qui }}\right), 8.86\left(\mathrm{dd}, J=4.0\right.$ and $1.5 \mathrm{~Hz}, J^{3}{ }_{\mathrm{H}-\mathrm{Hg}}$ $=9.7 \mathrm{~Hz}, 1 \mathrm{H}, 2-\mathrm{H}_{\text {qui }}$ ) ppm. $\mathrm{C}_{44} \mathrm{H}_{38} \mathrm{Cl}_{2} \mathrm{HgN}_{6} \mathrm{O}_{12} \mathrm{~S}_{2}$ : calcd. $\mathrm{C} 44.85$, H 3.25, N 7.13; found C 44.92, H 3.31, N 7.41.

$\left[\mathbf{C d}\{\mathbf{N N N t o s}(\mathbf{Q u i})\}_{2}\right]\left(\mathbf{C l O}_{4}\right)_{2}$ : The precipitation of the complex was obtained by lowering the temperature $\left(0^{\circ} \mathrm{C}\right)$. Yield $87 \%$ (white microcrystals). IR (KBr): $\tilde{v}=v_{\mathrm{C}-\mathrm{H}} 3065.8,2931.4,2861.1, v_{\mathrm{C}=\mathrm{N}}$ 1600.5, $v_{\mathrm{C}=\mathrm{C}} 1511.0, v_{\mathrm{ClO} 4}{ }^{-} 1088.7 \mathrm{~cm}^{-1} .{ }^{1} \mathrm{H}$ NMR $\left(\mathrm{CD}_{3} \mathrm{CN}, T=\right.$ $233 \mathrm{~K}): \delta=$ methyl protons, $2.56\left(\mathrm{~s}, 3 \mathrm{H}, \mathrm{CH}_{3}\right)$, aminomethyl protons $4.93,5.93$ (AB system, $J=14.1 \mathrm{~Hz}, J^{3}{ }_{\mathrm{H}-\mathrm{Cd}}=4.3 \mathrm{~Hz}, 2 \mathrm{H}$, pyr$\left.\mathrm{N}-\mathrm{CH}_{2}\right)$, pyridine, quinoline, and aromatic protons $7.30(\mathrm{~m}, 2 \mathrm{H}$, $\left.3^{\prime}-\mathrm{H}_{\mathrm{pyp}}, 5-\mathrm{H}_{\mathrm{qui}}\right), 7.57\left(\mathrm{~m}, 6 \mathrm{H}, 5^{\prime}-\mathrm{H}_{\mathrm{pyp}}, 6-\mathrm{H}_{\text {qui }}, \mathrm{H}_{\mathrm{ar}}\right), 7.91\left(\mathrm{td}, J^{\prime}=\right.$ 7.5 and $\left.1.3 \mathrm{~Hz}, 1 \mathrm{H}, 4^{\prime}-\mathrm{H}_{\mathrm{pyr}}\right), 8.00(\mathrm{dd}, J=4.4$ and $8.3 \mathrm{~Hz}, 1 \mathrm{H}$,
$\left.3-\mathrm{H}_{\text {qui }}\right), 8.25\left(\mathrm{~d}, J=7.9 \mathrm{~Hz}, 1 \mathrm{H}, 7-\mathrm{H}_{\text {qui }}\right), 8.52\left(\mathrm{~d}, J=6.0, J^{3}{ }_{\mathrm{H}-\mathrm{Cd}}\right.$ $\left.=9.8 \mathrm{~Hz}, 1 \mathrm{H}, 2^{\prime}-\mathrm{H}_{\mathrm{pyr}}\right), 8.84\left(\mathrm{dd}, J=8.1\right.$ and $\left.1.1 \mathrm{~Hz}, 1 \mathrm{H}, 4-\mathrm{H}_{\mathrm{qui}}\right)$, $8.96\left(\mathrm{dd}, J^{3}{ }_{\mathrm{H}-\mathrm{Cd}}=6.3 \mathrm{~Hz}, 1 \mathrm{H}, 2-\mathrm{H}_{\text {qui }}\right)$ ppm. $\mathrm{C}_{44} \mathrm{H}_{38} \mathrm{CdCl}_{2} \mathrm{~N}_{6} \mathrm{O}_{12} \mathrm{~S}_{2}$ : calcd. C 48.47, H 3.51, N 7.71; found C 48.38, H 3.60, N 7.52.

$\left[\mathbf{Z n}\{\mathbf{N N N t o s}(\mathbf{Q u i})\}_{2}\right]\left(\mathbf{C l O}_{4}\right)_{2}$ : The precipitation of the complex was obtained by addition of $\mathrm{Et}_{2} \mathrm{O}$. Diethyl ether was also used to wash the precipitate. Yield 92\% (white microcrystals). IR ( $\mathrm{KBr}): \tilde{v}=$ $v_{\mathrm{C}-\mathrm{H}}$ 3058.6, 2936.2, 2857.3, $v_{\mathrm{C}=\mathrm{N}}$ 1606.7, $v_{\mathrm{C}=\mathrm{C}} 1505.3,1464.8$, $v_{\mathrm{ClO} 4}{ }^{-} 1091.4 \mathrm{~cm}^{-1} .{ }^{1} \mathrm{H}$ NMR $\left(\mathrm{CD}_{3} \mathrm{CN}, T=227 \mathrm{~K}\right): \delta=$ methyl protons, $2.56\left(\mathrm{~s}, 3 \mathrm{H}, \mathrm{CH}_{3}\right)$, aminomethyl protons 5.00, $5.99(\mathrm{AB}$ system, $J=14.4 \mathrm{~Hz}, 2 \mathrm{H}$, pyr- $-\mathrm{CH}_{2}$ ), pyridine, quinoline, and aromatic protons $7.04\left(\mathrm{~d}, J=7.6\right.$ and $\left.1.1 \mathrm{~Hz}, 2 \mathrm{H}, 5-\mathrm{H}_{\text {qui }}\right), 7.29(\mathrm{t}$, $\left.2 \mathrm{H}, 3^{\prime}-\mathrm{H}_{\mathrm{pyr}}\right), 7.55\left(\mathrm{~m}, 6 \mathrm{H}, 5^{\prime}-\mathrm{H}_{\text {pyr }}, 6-\mathrm{H}_{\text {qui }}, \mathrm{H}_{\mathrm{ar}}\right), 7.94(\mathrm{td}, J=7.7$ and $\left.1.5 \mathrm{~Hz}, 1 \mathrm{H}, 4^{\prime}-\mathrm{H}_{\mathrm{pyr}}\right), 8.10(\mathrm{dd}, J=5.0$ and $8.3 \mathrm{~Hz}, 1 \mathrm{H}, 3-$ $\left.\mathrm{H}_{\text {qui }}\right), 8.24\left(\mathrm{~d}, J=8.3 \mathrm{~Hz}, 1 \mathrm{H}, 7-\mathrm{H}_{\text {qui }}\right), 8.66(\mathrm{~d}, J=5.5 \mathrm{~Hz}, 1 \mathrm{H}$, $\left.2^{\prime}-\mathrm{H}_{\text {pyr }}\right), 8.92\left(\mathrm{dd}, J=8.4\right.$ and $\left.1.3 \mathrm{~Hz}, 1 \mathrm{H}, 4-\mathrm{H}_{\text {qui }}\right), 8.96(\mathrm{dd}, J=$ $1.3 \mathrm{~Hz}, 1 \mathrm{H}, 2-\mathrm{H}_{\text {qui }}$ ) ppm. $\mathrm{C}_{44} \mathrm{H}_{38} \mathrm{Cl}_{2} \mathrm{~N}_{6} \mathrm{O}_{12} \mathrm{~S}_{2} \mathrm{Zn}$ : calcd. C 50.66, $\mathrm{H}$ 3.67, N 8.06; found C 51.01, H 3.57, N 8.12.

\section{Synthesis of Monochelate Dichloro Complexes}

[ $\mathbf{H g}\{\mathbf{N N N}(\mathbf{Q u i})\} \mathbf{C l}_{2}$ ]: A solution of $\mathrm{HgCl}_{2}(0.065 \mathrm{~g}, 0.24 \mathrm{mmol})$ in methanol $(2 \mathrm{~mL})$ was added slowly to a stirred solution of NNN(Qui) (0.62 g, $0.26 \mathrm{mmol})$ in methanol (2 mL). The complex, which precipitated immediately, was filtered off, washed with toluene, pentane, and dried under vacuum. Yellow microcrystals were obtained $(0.086 \mathrm{~g}, 0.17 \mathrm{mmol})$. Yield $70 \%$. IR $(\mathrm{KBr}): \tilde{v}=v_{\mathrm{N}-\mathrm{H}}$ $3175.4, v_{\mathrm{C}-\mathrm{H}} 3081.6,3027.9,2914.0 v_{\mathrm{C}=\mathrm{N}} 1606.7, v_{\mathrm{C}=\mathrm{C}} 1506.1 \mathrm{~cm}^{-1}$. ${ }^{1} \mathrm{H}$ NMR $\left(\mathrm{CD}_{3} \mathrm{OD}, T=298 \mathrm{~K}\right): \delta=$ aminomethyl protons, 4.71 (s, $2 \mathrm{H}$, pyr- $\mathrm{N}-\mathrm{CH}_{2}$ ), amine protons, 6.59 (br. s, $1 \mathrm{H}$, pyr- $\mathrm{NH}$ ), pyridine and quinoline protons $7.07\left(\mathrm{~d}, J=7.3 \mathrm{~Hz}, 1 \mathrm{H}, 7-\mathrm{H}_{\text {qui }}\right), 7.44$ (m, $\left.3 \mathrm{H}, 5-\mathrm{H}_{\text {qui }}, 6-\mathrm{H}_{\text {qui }}, 3^{\prime}-\mathrm{H}_{\mathrm{pyr}}\right), 7.55\left(\mathrm{~d}, J=7.7 \mathrm{~Hz}, 1 \mathrm{H}, 5^{\prime}-\mathrm{H}_{\mathrm{pyr}}\right.$ ), $7.60\left(\mathrm{dd}, J=8.3 \mathrm{~Hz}, 1 \mathrm{H}, 3-\mathrm{H}_{\text {qui }}\right), 7.89(\mathrm{td}, J=7.7$ and $1.8 \mathrm{~Hz}, 1$ $\left.\mathrm{H}, 4^{\prime}-\mathrm{H}_{\mathrm{pyr}}\right), 8.31\left(\mathrm{dd}, J=1.7 \mathrm{~Hz}, 1 \mathrm{H}, 4-\mathrm{H}_{\text {qui }}\right), 8.61(\mathrm{~d}, J=4.0 \mathrm{~Hz}$, $\left.1 \mathrm{H}, 2^{\prime}-\mathrm{H}_{\mathrm{pyr}}\right), 8.86\left(\mathrm{dd}, J=4.2 \mathrm{~Hz}, 1 \mathrm{H}, 2-\mathrm{H}_{\text {qui }}\right) \mathrm{ppm}$. $\mathrm{C}_{15} \mathrm{H}_{13} \mathrm{Cl}_{2} \mathrm{HgN}_{3}$ : calcd. C 35.55, $\mathrm{H} 2.59, \mathrm{~N} 8.29$; found $\mathrm{C} 35.61, \mathrm{H}$ 2.47, N 8.31 .

The following complexes were synthesized in an analogous way using the appropriate ligand and chloride salts.

[Cd\{NNN(Qui)\} $\mathbf{C l}_{2}$ ]: Yield 82\% (white microcrystals). IR (KBr): $\tilde{v}=v_{\mathrm{N}-\mathrm{H}} 3144.4, v_{\mathrm{C}-\mathrm{H}} 3045.7,2927.2, v_{\mathrm{C}=\mathrm{N}}$ 1604.4, $v_{\mathrm{C}=\mathrm{C}}$ 1505.7, $1479.3 \mathrm{~cm}^{-1} \cdot{ }^{1} \mathrm{H}$ NMR $\left(\mathrm{CD}_{3} \mathrm{CN}, T=333 \mathrm{~K}\right): \delta=$ aminomethyl protons, 4.64 (s, $2 \mathrm{H}$, pyr-N-CH ), amine protons, 5.15 (br. s, $1 \mathrm{H}$, pyr-NH), pyridine and quinoline protons $7.53\left(\mathrm{~m}, 2 \mathrm{H}, 5^{\prime}-\mathrm{H}_{\mathrm{pyp}}, 3^{\prime}-\right.$ $\left.\mathrm{H}_{\text {pyr }}\right), 7.75\left(\mathrm{~m}, 2 \mathrm{H}, 6-\mathrm{H}_{\text {qui }}, 3-\mathrm{H}_{\text {qui }}\right), 7.89\left(\mathrm{~m}, 2 \mathrm{H}, 5-\mathrm{H}_{\text {qui }}, 7-\mathrm{H}_{\text {qui }}\right)$, $7.98\left(\mathrm{td}, J=7.7\right.$ and $\left.1.7 \mathrm{~Hz}, 1 \mathrm{H}, 4^{\prime}-\mathrm{H}_{\mathrm{pyr}}\right), 8.55(\mathrm{dd}, J=8.5$ and $\left.1.5 \mathrm{~Hz}, 1 \mathrm{H}, 4-\mathrm{H}_{\text {qui }}\right), 8.81\left(\mathrm{~d}, J=4.5 \mathrm{~Hz}, 1 \mathrm{H}, 2^{\prime}-\mathrm{H}_{\mathrm{pyr}}\right), 8.86(\mathrm{dd}$, $J=4.4 \mathrm{~Hz}, 1 \mathrm{H}, 2-\mathrm{H}_{\text {quil }}$ ) ppm. $\mathrm{C}_{15} \mathrm{H}_{13} \mathrm{CdCl}_{2} \mathrm{~N}_{3}$ : calcd. $\mathrm{C} 43.04, \mathrm{H}$ 3.13, N 10.04; found C 43.09, H 3.20, N 10.11.

[Zn\{NNN(Qui)\} $\mathbf{C l}_{\mathbf{2}}$ ]: Yield 84\% (pale yellow microcrystals). IR $(\mathrm{KBr}): \tilde{v}=v_{\mathrm{N}-\mathrm{H}} 3164.2, v_{\mathrm{C}-\mathrm{H}} 3078.6,3052.3,2920.7,2854.8, v_{\mathrm{C}=\mathrm{N}}$ $1611.4, v_{\mathrm{C}=\mathrm{C}} 1512.2,1453.0 \mathrm{~cm}^{-1} .{ }^{1} \mathrm{H} \mathrm{NMR}\left(\mathrm{CD}_{3} \mathrm{CN}, T=298 \mathrm{~K}\right)$ : $\delta=$ aminomethyl protons, 4.70 (br. s, $2 \mathrm{H}$, pyr- $\mathrm{N}-\mathrm{CH}_{2}$ ), amine protons no signal, pyridine and quinoline protons $7.59\left(\mathrm{~m}, 2 \mathrm{H}, 5^{\prime}\right.$ $\left.\mathrm{H}_{\text {pyr }}, 3^{\prime}-\mathrm{H}_{\text {pyr }}\right), 7.78\left(\mathrm{~m}, 2 \mathrm{H}, 6-\mathrm{H}_{\text {qui }}, 3-\mathrm{H}_{\text {qui }}\right), 7.95\left(\mathrm{~m}, 2 \mathrm{H}, 5-\mathrm{H}_{\text {qui }}\right.$, $7-\mathrm{H}_{\text {qui }}$ ), 7.98 (br. t, $J=7.4 \mathrm{~Hz}, 1 \mathrm{H}, 4^{\prime}-\mathrm{H}_{\text {pyr }}$ ), 8.63 (br. d, $J=8.3 \mathrm{~Hz}$, $1 \mathrm{H}, 4-\mathrm{H}_{\text {qui }}$ ), 8.95 (br. d, $J=4.7 \mathrm{~Hz}, 1 \mathrm{H}, 2^{\prime}-\mathrm{H}_{\text {pyr }}$ ), 9.24 (br. d, $J=$ $3.8 \mathrm{~Hz}, 1 \mathrm{H}, 2-\mathrm{H}_{\text {qui }}$ ) ppm. $\mathrm{C}_{15} \mathrm{H}_{13} \mathrm{Cl}_{2} \mathrm{~N}_{3} \mathrm{Zn}$ : calcd. C 48.49, $\mathrm{H} 3.53$, $\mathrm{N}$ 11.31; found C 48.62, H 3.49, N 11.20.

[Hg\{NSN(Qui)\} $\mathbf{C l}_{2}$ ]: Yield 89\% (white microcrystals). IR (KBr): $\tilde{v}$ $=v_{\mathrm{C}-\mathrm{H}} 3027.9,2954.2,2880.4 v_{\mathrm{C}=\mathrm{N}} 1600.0, v_{\mathrm{C}=\mathrm{C}} 1499.4,1486.0$, $1439.1 \mathrm{~cm}^{-1} .{ }^{1} \mathrm{H}$ NMR $\left(\mathrm{CD}_{3} \mathrm{CN}, T=298 \mathrm{~K}\right): \delta=$ methylthio protons, $4.56\left(\mathrm{~s}, 2 \mathrm{H}\right.$, pyr-S- $\left.\mathrm{CH}_{2}\right)$, pyridine and quinoline protons 7.38 
(dd, $J=4.4$ and $\left.7.7 \mathrm{~Hz}, 1 \mathrm{H}, 3^{\prime}-\mathrm{H}_{\mathrm{pyr}}\right), 7.54(\mathrm{~d}, J=7.7 \mathrm{~Hz}, 1 \mathrm{H}$, $\left.5^{\prime}-\mathrm{H}_{\text {pyr }}\right), 7.60\left(\mathrm{t}, J=8.1\right.$ and $\left.7.3 \mathrm{~Hz}, 1 \mathrm{H}, 6-\mathrm{H}_{\mathrm{qui}}\right), 7.67(\mathrm{dd}, J=8.4$ and $\left.4.4 \mathrm{~Hz}, 1 \mathrm{H}, 3-\mathrm{H}_{\text {qui }}\right), 7.82\left(\mathrm{td}, J=7.7\right.$ and $\left.1.8 \mathrm{~Hz}, 1 \mathrm{H}, 4^{\prime}-\mathrm{H}_{\text {pyr }}\right)$, $7.90\left(\mathrm{~d}, 1 \mathrm{H}, 5-\mathrm{H}_{\mathrm{qui}}\right), 7.98\left(\mathrm{~d}, 1 \mathrm{H}, 7-\mathrm{H}_{\mathrm{qui}}\right), 8.42(\mathrm{dd}, J=1.8 \mathrm{~Hz}$, $\left.1 \mathrm{H}, 4-\mathrm{H}_{\text {qui }}\right), 8.63\left(\mathrm{~d}, 1 \mathrm{H}, 2^{\prime}-\mathrm{H}_{\text {pyr }}\right), 9.06\left(\mathrm{dd}, 1 \mathrm{H}, 2-\mathrm{H}_{\text {qui }}\right) \mathrm{ppm}$. $\mathrm{C}_{15} \mathrm{H}_{12} \mathrm{Cl}_{2} \mathrm{HgN}_{2} \mathrm{~S}$ : C 34.39, $\mathrm{H}$ 2.31, N 5.35; found C 34.12, H 2.27, N 5.51 .

[Cd\{NSN(Qui)\} $\mathbf{C l}_{2}$ ]: Yield 91\% (white microcrystals). IR (KBr): $\tilde{v}$ $=v_{\mathrm{C}-\mathrm{H}} 3072.0,2966.7,2907.5 v_{\mathrm{C}=\mathrm{N}}$ 1597.8, $v_{\mathrm{C}=\mathrm{C}} 1499.1,1485.9$, $1459.6 \mathrm{~cm}^{-1} .{ }^{1} \mathrm{H}$ NMR $\left(\mathrm{CD}_{3} \mathrm{CN}, T=333 \mathrm{~K}\right): \delta=$ methylthio protons, $4.58\left(\mathrm{~s}, 2 \mathrm{H}\right.$, pyr-S- $\left.\mathrm{CH}_{2}\right)$, pyridine and quinoline protons 7.35 $\left(\mathrm{m}, 2 \mathrm{H}, 5^{\prime}-\mathrm{H}_{\text {pyr }}, 3^{\prime}-\mathrm{H}_{\text {pyr }}\right), 7.75\left(\mathrm{~m}, 3 \mathrm{H}, 6-\mathrm{H}_{\text {qui }}, 3-\mathrm{H}_{\text {qui }}, 4^{\prime}-\mathrm{H}_{\text {pyr }}\right)$, $8.03\left(\mathrm{~d}, J=8.1 \mathrm{~Hz}, 1 \mathrm{H}, 5-\mathrm{H}_{\text {qui }}\right), 8.30\left(\mathrm{~d}, J=6.9 \mathrm{~Hz}, 1 \mathrm{H}, 7-\mathrm{H}_{\text {qui }}\right)$, $8.42\left(\mathrm{dd}, J=8.5\right.$ and $\left.1.8 \mathrm{~Hz}, 1 \mathrm{H}, 4-\mathrm{H}_{\text {qui }}\right), 8.83(\mathrm{~d}, J=4.9 \mathrm{~Hz}, 1 \mathrm{H}$, $2^{\prime}-\mathrm{H}_{\text {pyr }}$ ), 9.06 (dd, $J=3.2 \mathrm{~Hz}, 1 \mathrm{H}, 2-\mathrm{H}_{\text {qui }}$ ) ppm. $\mathrm{C}_{15} \mathrm{H}_{12} \mathrm{CdCl}_{2} \mathrm{~N}_{2} \mathrm{~S}$ : calcd. C 41.35, H 2.78, N 6.43; found C 41.22, H 2.87, N 6.45.

[Zn\{ $\left.\mathbf{N S N}(\mathbf{Q u i})\} \mathbf{C l}_{\mathbf{2}}\right]$ : The precipitation of the complex was achieved by volume reduction followed by toluene addition. Yield $86 \%$ (white microcrystals). IR (KBr): $\tilde{v}=v_{\mathrm{C}-\mathrm{H}} 3085.2$, 3052.3, 2993.1, 2914.1, $2841.7 v_{\mathrm{C}=\mathrm{N}} 1611.0, v_{\mathrm{C}=\mathrm{C}} 1505.7,1485.9,1446.4 \mathrm{~cm}^{-1} .{ }^{1} \mathrm{H}$ NMR $\left(\mathrm{CD}_{3} \mathrm{CN}, T=298 \mathrm{~K}\right): \delta=$ methylthio protons, $4.58(\mathrm{~s}, 2 \mathrm{H}$, pyr-S- $\left.\mathrm{CH}_{2}\right)$, pyridine and quinoline protons $7.54\left(\mathrm{~m}, 2 \mathrm{H}, 5^{\prime}-\mathrm{H}_{\text {pyr }}\right.$, $\left.6-\mathrm{H}_{\text {qui }}\right), 7.80\left(\mathrm{dd}, J_{\prime}=5.5\right.$ and $\left.8.3 \mathrm{~Hz}, 1 \mathrm{H}, 3^{\prime}-\mathrm{H}_{\text {pyr }}\right), 7.88(\mathrm{dd}, J=$ 8.3 and $\left.4.9 \mathrm{~Hz}, 1 \mathrm{H}, 3-\mathrm{H}_{\text {qui }}\right), 7.99(\mathrm{td}, J=8.3,7.7$ and $1.6 \mathrm{~Hz}, 1$ $\left.\mathrm{H}, 4^{\prime}-\mathrm{H}_{\mathrm{pyr}}\right), 8.22\left(\mathrm{dd}, J=8.3\right.$ and $\left.1.4 \mathrm{~Hz}, 1 \mathrm{H}, 5-\mathrm{H}_{\text {qui }}\right), 8.40$ (dd, $J$ $\left.=7.4 \mathrm{~Hz}, 1 \mathrm{H}, 7-\mathrm{H}_{\text {qui }}\right), 8.70\left(\mathrm{dd}, J=1.6 \mathrm{~Hz}, 1 \mathrm{H}, 4-\mathrm{H}_{\text {qui }}\right), 9.11(\mathrm{~d}$, $\left.1 \mathrm{H}, 2^{\prime}-\mathrm{H}_{\text {pyr }}\right), 9.75$ (dd, $\left.1 \mathrm{H}, 2-\mathrm{H}_{\text {qui }}\right)$ ppm. $\mathrm{C}_{15} \mathrm{H}_{12} \mathrm{Cl}_{2} \mathrm{~N}_{2} \mathrm{SZn}: \mathrm{C}$ 46.36, H 3.11, N 7.21; found C 46.43, H 3.07, N 7.26.

[Hg\{NNNtos(Qui)\} $\mathbf{C l}_{2}$ ]: Yield $64 \%$ (white microcrystals). IR $(\mathrm{KBr}): \tilde{v}=v_{\mathrm{C}-\mathrm{H}} 3068.2,2914.0 v_{\mathrm{C}=\mathrm{N}} 1606.7, v_{\mathrm{C}=\mathrm{C}} 1519.1 \mathrm{~cm}^{-1} \cdot{ }^{1} \mathrm{H}$ NMR $\left(\mathrm{CD}_{3} \mathrm{CN}, T=233 \mathrm{~K}\right): \delta=$ methyl protons, $2.44(\mathrm{~s}, 3 \mathrm{H}$, $\mathrm{CH}_{3}$ ), aminomethyl protons $4.71\left(\mathrm{~s}, 2 \mathrm{H}\right.$, pyr- $\mathrm{N}-\mathrm{CH}_{2}$ ), pyridine, quinoline, and aromatic protons $7.29\left(\mathrm{~d}, J_{\mathrm{b}-\mathrm{c}}=8.05 \mathrm{~Hz}, 2 \mathrm{H}, \mathrm{H}_{\mathrm{ar}}\right)$, $7.35\left(\mathrm{t}, J=5.1 \mathrm{~Hz}, 1 \mathrm{H}, 3^{\prime}-\mathrm{H}_{\mathrm{pyr}}\right), 7.55\left(\mathrm{~m}, 4 \mathrm{H}, 5-\mathrm{H}_{\text {qui }}, 6-\mathrm{H}_{\text {qui }}\right.$, $\left.\mathrm{H}_{\mathrm{ar}}\right), 7.62\left(\mathrm{~m}, 2 \mathrm{H}, 5^{\prime}-\mathrm{H}_{\mathrm{pyr}}, 3-\mathrm{H}_{\mathrm{qui}}\right), 7.84(\mathrm{td}, J=8.0,1.5$, and $\left.8.4 \mathrm{~Hz}, 1 \mathrm{H}, 4^{\prime}-\mathrm{H}_{\mathrm{pyr}}\right), 7.99\left(\mathrm{dd}, J=7.9\right.$ and $1.7 \mathrm{~Hz}, 1 \mathrm{H}, 7-\mathrm{H}_{\text {qui }}$ ), $8.43\left(\mathrm{dd}, J=8.4\right.$ and $\left.1.8 \mathrm{~Hz}, 1 \mathrm{H}, 4-\mathrm{H}_{\text {qui }}\right), 8.51\left(\mathrm{~d}, 1 \mathrm{H}, 2^{\prime}-\mathrm{H}_{\text {pyr }}\right)$, 8.85 (dd, $J=4.4 \mathrm{~Hz}, 1 \mathrm{H}, 2-\mathrm{H}_{\text {qui }}$ ) ppm. $\mathrm{C}_{22} \mathrm{H}_{19} \mathrm{Cl}_{2} \mathrm{HgN}_{3} \mathrm{O}_{2} \mathrm{~S}$ : calcd. C 39.98, H 2.90, N 6.36; found C 40.02, H 2.87, N 6.39.

[Cd\{NNNtos(Qui)\} $\mathbf{C l}_{\mathbf{2}}$ ]: Yield 94\% (white microcrystals). IR ( $\mathrm{KBr}$ ): $\tilde{v}=v_{\mathrm{C}-\mathrm{H}}$ 3072.0, 2966.7, $2868.0 \quad v_{\mathrm{C}=\mathrm{N}}$ 1604.4, $v_{\mathrm{C}=\mathrm{C}}$ 1512.2, $1453.0 \mathrm{~cm}^{-1} .{ }^{1} \mathrm{H}$ NMR $\left(\mathrm{CD}_{3} \mathrm{CN}, T=333 \mathrm{~K}\right): \delta=$ methyl protons, $2.44\left(\mathrm{~s}, 3 \mathrm{H}, \mathrm{CH}_{3}\right)$, aminomethyl protons 5.24 (s, $2 \mathrm{H}$, pyr- $\left.\mathrm{N}-\mathrm{CH}_{2}\right)$, pyridine, quinoline, and aromatic protons $7.33(\mathrm{~d}, J=8.3 \mathrm{~Hz}, 2 \mathrm{H}$, $\left.\mathrm{H}_{\mathrm{ar}}\right), 7.42\left(\mathrm{~m}, 4 \mathrm{H}, 3^{\prime}-\mathrm{H}_{\text {pyr }}, 6-\mathrm{H}_{\text {qui }}, \mathrm{H}_{\mathrm{ar}}\right), 7.54(\mathrm{~d}, J=5.1 \mathrm{~Hz}, 1 \mathrm{H}$, $\left.5-\mathrm{H}_{\text {qui }}\right), 7.61\left(\mathrm{~d}, 1 \mathrm{H}, 5^{\prime}-\mathrm{H}_{\text {pyr }}\right), 7.72(\mathrm{dd}, J=4.1$ and $8.3 \mathrm{~Hz}, 1 \mathrm{H}$, $\left.3-\mathrm{H}_{\text {qui }}\right), 7.92\left(\mathrm{td}, J=6.2\right.$ and $\left.1.5 \mathrm{~Hz}, 1 \mathrm{H}, 4^{\prime}-\mathrm{H}_{\text {pyr }}\right), 8.03(\mathrm{dd}, J=$ 8.2 and $\left.1.0 \mathrm{~Hz}, 1 \mathrm{H}, 7-\mathrm{H}_{\text {qui }}\right), 8.52\left(\mathrm{dd}, J=1.5 \mathrm{~Hz}, 1 \mathrm{H}, 4-\mathrm{H}_{\text {qui }}\right.$ ), $8.65\left(\mathrm{~d}, J=6.2 \mathrm{~Hz}, 1 \mathrm{H}, 2^{\prime}-\mathrm{H}_{\text {pyr }}\right), 9.04\left(\mathrm{dd}, 1 \mathrm{H}, 2-\mathrm{H}_{\text {qui }}\right) \mathrm{ppm}$. $\mathrm{C}_{22} \mathrm{H}_{19} \mathrm{CdCl}_{2} \mathrm{~N}_{3} \mathrm{O}_{2} \mathrm{~S}$ : calcd. C 46.13, H 3.34, N 7.34; found C 46.21, $\mathrm{H} 3.24, \mathrm{~N} 7.42$.

[Zn\{NNNtos(Qui)\} $\mathbf{C l}_{\mathbf{2}}$ ]: Yield 96\% (white microcrystals). IR ( $\mathrm{KBr}$ ): $\tilde{v}=v_{\mathrm{C}-\mathrm{H}} 3065.4,3032.5,2960.1,2927.2 v_{\mathrm{C}=\mathrm{N}} 1617.6, v_{\mathrm{C}=\mathrm{C}} 1512.2$, $1492.5,1439.9 \mathrm{~cm}^{-1} \cdot{ }^{1} \mathrm{H}$ NMR $\left(\mathrm{CD}_{3} \mathrm{OD}, T=333 \mathrm{~K}\right): \delta=$ methyl protons, $2.40\left(\mathrm{~s}, 3 \mathrm{H}, \mathrm{CH}_{3}\right)$, aminomethyl protons $5.32(\mathrm{~s}, 2 \mathrm{H}$, pyr$\left.\mathrm{N}-\mathrm{CH}_{2}\right)$, pyridine, quinoline, and aromatic protons $7.22(\mathrm{~d}, J=$ $\left.7.9 \mathrm{~Hz}, 2 \mathrm{H}, \mathrm{H}_{\mathrm{ar}}\right), 7.27\left(\mathrm{td}, J=7.7\right.$ and $\left.1.1 \mathrm{~Hz}, 1 \mathrm{H}, 3^{\prime}-\mathrm{H}_{\mathrm{pyr}}\right), 7.48$ (m, $\left.4 \mathrm{H}, 3-\mathrm{H}_{\text {qui }}, 6-\mathrm{H}_{\text {qui }}, \mathrm{H}_{\mathrm{ar}}\right), 7.59(\mathrm{dd}, J=7.4$ and $1.5 \mathrm{~Hz}, 1 \mathrm{H}, 5-$ $\left.\mathrm{H}_{\text {qui }}\right), 7.71\left(\mathrm{~d}, J=7.7 \mathrm{~Hz}, 1 \mathrm{H}, 5^{\prime}-\mathrm{H}_{\text {pyr }}\right), 7.81(\mathrm{td}, J=1.7 \mathrm{~Hz}, 1 \mathrm{H}$, $\left.4^{\prime}-\mathrm{H}_{\text {pyr }}\right), 7.91\left(\mathrm{dd}, J=8.2 \mathrm{~Hz}, 1 \mathrm{H}, 7-\mathrm{H}_{\text {qui }}\right), 8.31(\mathrm{dd}, J=8.4$ and $\left.1.6 \mathrm{~Hz}, 1 \mathrm{H}, 4-\mathrm{H}_{\text {qui }}\right), 8.43\left(\mathrm{~d}, J=4.7 \mathrm{~Hz}, 1 \mathrm{H}, 2^{\prime}-\mathrm{H}_{\text {pyr }}\right), 8.73(\mathrm{dd}$,
$1 \mathrm{H}, 2-\mathrm{H}_{\text {qui }}$ ) ppm. $\mathrm{C}_{22} \mathrm{H}_{19} \mathrm{Cl}_{2} \mathrm{~N}_{3} \mathrm{O}_{2} \mathrm{SZn}$ : calcd. C 50.26, H 3.64, N 7.99; found C 50.32, H 3.73, N 8.05.

Potentiometric Titrations and Calculations: The potentiometric determinations were carried out by a Metrohm $654 \mathrm{pH}-$ meter equipped with a Metrohm glass electrode calibrated at $25^{\circ} \mathrm{C}$ by means of standard Metrohm buffer solutions ( $\mathrm{pH} 4$ and 7). All the measurements were carried out under $\mathrm{N}_{2}$ stream in a thermostatted potentiometric cell.

The appropriate quantity of the ligands NSN(Py), NSN(Qui), and $\mathrm{NNN}$ (Qui) were poured into volumetric flasks $(250 \mathrm{~mL})$ and the appropriate volumes of $\mathrm{HCl}(0.1 \mathrm{M})$ were added to obtain $\mathrm{NSN}(\mathrm{Py}) \cdot$ $2 \mathrm{HCl}, \mathrm{NSN}($ Qui) $\cdot 2 \mathrm{HCl}$, and $\mathrm{NNN}($ Qui) $\cdot 3 \mathrm{HCl}$, respectively. Addition of $\mathrm{NaCl}(0.1 \mathrm{M})$ in water yielded the solutions at pre-determined concentration and ionic strength $([$ Ligand $\bullet n \mathrm{HCl}]=$ $\left.1 \times 10^{-3} \mathrm{M} ; I=0.1 \mathrm{M}\right)$.

An aliquot $(50 \mathrm{~mL})$ of the solution under study was then titrated with $\mathrm{NaOH}(0.1 \mathrm{M}, I=0.1 \mathrm{M})$. Evaluation of acid/base constants from the $\mathrm{pH}$ values vs. volume of $\mathrm{NaOH}$ added, was obtained by routines written using the SCIENTIST ${ }^{\mathrm{TM}}$ program. For calculation details see the Supporting Information.

Spectrophotometric Determination of the Complex Formation Constants: All the experiments were carried out in water (degassed under $\mathrm{N}_{2}$ stream; $\left.\mathrm{pH} \approx 6.5\right)$ and in thermostatted $\left(25^{\circ} \mathrm{C}\right)$ flasks. A standard stock of solutions $\left(50 \mathrm{~mL} ; 3 \times 10^{-4} \mathrm{M}\right)$ of the ligands [NNN(Qui), NSN(Qui), and NSN(Py)] was prepared by dissolving a weighted amount of the appropriate ligand in a volumetric flask and diluting to the mark with $\mathrm{H}_{2} \mathrm{O}$. The ligand solutions (7$9 \times 10^{-5} \mathrm{M}$ ) used in the experiment were then prepared by dilution of the stock solution. The ligand solution was titrated by adding microaliquots of a standard solution of $\mathrm{MCl}_{2}\left(\mathrm{M}=\mathrm{Hg}, \mathrm{Zn}\right.$; $\left[\mathrm{MCl}_{2}\right]$ $=0.01 \mathrm{M})$ and $\mathrm{Cd}\left(\mathrm{ClO}_{4}\right)_{2}\left(\left[\mathrm{Cd}\left(\mathrm{ClO}_{4}\right)_{2}\right]=0.5 \mathrm{M}\right)$ by means of a micropipette. The ensuing absorbance values at different wavelengths were recorded at $25^{\circ} \mathrm{C}$ and the evaluation of stepwise stability constants from the absorbance vs. volume of $\mathrm{MCl}_{2} \mathrm{~mL}$ data was achieved by the speculative use of the program HYPER-

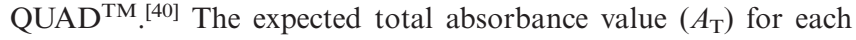
solution is given as $A_{\mathrm{T}}=\Sigma_{i} \varepsilon_{i} \mathrm{c}_{i}$, where $\varepsilon_{i}$ and $\mathrm{c}_{i}$ are the molar extinction coefficient and the concentration of the involved species, respectively. The iterative adjustment of calculated values of $\varepsilon_{\mathrm{ML}}$ and $\varepsilon_{\mathrm{ML} 2}$ and subsequent refinement of the parameters was continued until the correlation matrix was minimized. The values of refined $\varepsilon_{\mathrm{L}}$ are in good agreement with the values measured by the Lambert-Beer experiment. UV/Vis titration spectra are reported in the Supporting Information.

The metal exchange spectrophotometric titrations were performed by addition of a weighted amount of $\mathrm{Zn}\left(\mathrm{ClO}_{4}\right)_{2} \cdot 6 \mathrm{H}_{2} \mathrm{O}\left(1 \times 10^{-4} \leq\right.$ $\left.\left[\mathrm{Zn}\left(\mathrm{ClO}_{4}\right)_{2}\right] \leq 1 \times 10^{-2} \mathrm{M}\right)$ or of microaliquots of a standard stock solution $(0.01 \mathrm{M})$ of $\mathrm{Cd}\left(\mathrm{ClO}_{4}\right)_{2} \cdot 6 \mathrm{H}_{2} \mathrm{O}$ to solutions of $[\mathrm{Hg}$ $\{\mathrm{NNN}($ Qui $\left.)\} \mathrm{Cl}_{2}\right]$ or $[\mathrm{Zn}\{\mathrm{NNN}(\mathrm{Qui})\}]^{2+}\left(1 \times 10^{-4} \mathrm{M}\right)$, respectively. The absorbance values were taken at $\lambda=250 \mathrm{~nm}$. The exchange constants from the absorbance vs. $\left[\mathrm{M}\left(\mathrm{ClO}_{4}\right)_{2}\right]$ values were obtained by routines written using the SCIENTIST ${ }^{\mathrm{TM}}$ program. For calculation details see the Supporting Information.

X-ray Structural Determination: Well-formed crystals of the complexes $\left[\mathrm{Hg}\{\mathrm{NSN}(\mathrm{Qui})\} \mathrm{Cl}_{2}\right](\mathbf{1}),\left[\mathrm{Hg}\{\mathrm{NSN}(\mathrm{Qui})\}_{2}\left\{\mathrm{OClO}_{3}\right\}\right]\left(\mathrm{ClO}_{4}\right)$ (2), and $\left[\mathrm{Zn}\{\mathrm{NNN}(\mathrm{Qui})\} \mathrm{Cl}_{2}\right]$ (3) suitable for X-ray analysis, were mounted on the top of a glass fiber and transferred to either a STADI4 diffractometer equipped with a CCD camera $(\mathbf{1}, \mathbf{2})$ or to a Nonius DIP-1030H system (3). The latter was generously made available by colleagues at the Department of Chemical Sciences of the University of Trieste, Italy. During the crystallization process, 
Table 5. Selected bond lengths $[\AA]$ and bond angles $\left[{ }^{\circ}\right]$ for the complexes 1-3.

\begin{tabular}{|c|c|c|c|c|c|c|}
\hline & $\begin{array}{l}\mathbf{1} \\
T B P Y-5-12-C\end{array}$ & $T B P Y-5-12-A$ & 2 & & 3 & \\
\hline $\mathrm{Hg}-\mathrm{Cl}(1)$ & $2.455(4)$ & $2.494(4)$ & $\mathrm{Hg}-\mathrm{S}$ & $2.621(4)$ & $\mathrm{Zn}-\mathrm{Cl}(1)$ & $2.252(1)$ \\
\hline $\mathrm{Hg}-\mathrm{Cl}(2)$ & $2.450(4)$ & $2.428(4)$ & $\mathrm{Hg}-\mathrm{S}^{\prime}$ & $2.749(5)$ & $\mathrm{Zn}-\mathrm{Cl}(2)$ & $2.343(1)$ \\
\hline $\mathrm{Hg}-\mathrm{S}$ & $2.759(4)$ & $2.748(3)$ & $\mathrm{Hg}-\mathrm{N}(1)$ & $2.63(1)$ & $\mathrm{Zn}-\mathrm{N}(1)$ & $2.124(3)$ \\
\hline $\mathrm{Hg}-\mathrm{N}(1)$ & $2.350(9)$ & $2.38(1)$ & $\mathrm{Hg}-\mathrm{N}\left(1^{\prime}\right)$ & $2.23(1)$ & $\mathrm{Zn}-\mathrm{N}(2)$ & $2.234(3)$ \\
\hline \multirow[t]{2}{*}{$\mathrm{Hg}-\mathrm{N}(2)$} & $2.44(1)$ & $2.44(1)$ & $\mathrm{Hg}-\mathrm{N}(2)$ & $2.28(1)$ & $\mathrm{Zn}-\mathrm{N}(3)$ & $2.156(3)$ \\
\hline & & & $\mathrm{Hg}-\mathrm{O}\left(1^{\prime}\right)$ & $2.60(1)$ & & \\
\hline $\mathrm{Cl}(1)-\mathrm{Hg}-\mathrm{Cl}(2)$ & $105.7(1)$ & $106.0(1)$ & $\mathrm{S}-\mathrm{Hg}-\mathrm{S}^{\prime}$ & $111.4(1)$ & $\mathrm{Cl}(1)-\mathrm{Zn}-\mathrm{Cl}(2)$ & 111.9(1) \\
\hline $\mathrm{Cl}(1)-\mathrm{Hg}-\mathrm{S}$ & 163.1(1) & $156.5(1)$ & $\mathrm{S}-\mathrm{Hg}-\mathrm{N}(1)$ & $74.0(3)$ & $\mathrm{Cl}(1)-\mathrm{Zn}-\mathrm{N}(1)$ & $105.3(1)$ \\
\hline $\mathrm{Cl}(1)-\mathrm{Hg}-\mathrm{N}(1)$ & $97.5(3)$ & $93.8(3)$ & $\mathrm{S}-\mathrm{Hg}-\mathrm{N}\left(1^{\prime}\right)$ & $118.2(4)$ & $\mathrm{Cl}(1)-\mathrm{Zn}-\mathrm{N}(2)$ & $104.8(1)$ \\
\hline $\mathrm{Cl}(1)-\mathrm{Hg}-\mathrm{N}(2)$ & $94.6(3)$ & $89.4(3)$ & $\mathrm{S}-\mathrm{Hg}-\mathrm{N}(2)$ & $78.0(3)$ & $\mathrm{Cl}(1)-\mathrm{Zn}-\mathrm{N}(3)$ & $105.9(1)$ \\
\hline $\mathrm{Cl}(2)-\mathrm{Hg}-\mathrm{S}$ & $90.8(1)$ & $97.1(1)$ & $\mathrm{S}-\mathrm{Hg}-\mathrm{O}\left(1^{\prime}\right)$ & $144.1(3)$ & $\mathrm{Cl}(2)-\mathrm{Zn}-\mathrm{N}(1)$ & $94.6(1)$ \\
\hline $\mathrm{Cl}(2)-\mathrm{Hg}-\mathrm{N}(1)$ & $128.0(3)$ & $128.1(3)$ & $\mathrm{S}^{\prime}-\mathrm{Hg}-\mathrm{N}(1)$ & $170.6(3)$ & $\mathrm{Cl}(2)-\mathrm{Zn}-\mathrm{N}(2)$ & $143.2(1)$ \\
\hline $\mathrm{Cl}(2)-\mathrm{Hg}-\mathrm{N}(2)$ & $127.6(2)$ & $129.7(3)$ & $\mathrm{S}^{\prime}-\mathrm{Hg}-\mathrm{N}\left(1^{\prime}\right)$ & $76.3(3)$ & $\mathrm{Cl}(2)-\mathrm{Zn}-\mathrm{N}(3)$ & $92.6(1)$ \\
\hline $\mathrm{S}-\mathrm{Hg}-\mathrm{N}(1)$ & $74.7(3)$ & $74.7(3)$ & $\mathrm{S}^{\prime}-\mathrm{Hg}-\mathrm{N}(2)$ & $105.2(3)$ & $\mathrm{N}(1)-\mathrm{Zn}-\mathrm{N}(2)$ & $77.0(1)$ \\
\hline $\mathrm{S}-\mathrm{Hg}-\mathrm{N}(2)$ & $71.6(3)$ & $72.2(3)$ & $\mathrm{S}^{\prime}-\mathrm{Hg}-\mathrm{O}\left(1^{\prime}\right)$ & $101.4(3)$ & $\mathrm{N}(1)-\mathrm{Zn}-\mathrm{N}(3)$ & $142.6(1)$ \\
\hline \multirow[t]{6}{*}{$\mathrm{N}(1)-\mathrm{Hg}-\mathrm{N}(2)$} & $95.2(3)$ & $97.2(4)$ & $\mathrm{N}(1)-\mathrm{Hg}-\mathrm{N}\left(1^{\prime}\right)$ & $94.5(4)$ & $\mathrm{N}(2)-\mathrm{Zn}-\mathrm{N}(3)$ & $75.3(1)$ \\
\hline & & & $\mathrm{N}(1)-\mathrm{Hg}-\mathrm{N}(2)$ & $83.2(4)$ & & \\
\hline & & & $\mathrm{N}(1)-\mathrm{Hg}-\mathrm{O}\left(1^{\prime}\right)$ & $75.7(4)$ & & \\
\hline & & & $\mathrm{N}\left(1^{\prime}\right)-\mathrm{Hg}-\mathrm{N}(2)$ & $162.4(4)$ & & \\
\hline & & & $\mathrm{N}\left(1^{\prime}\right)-\mathrm{Hg}-\mathrm{O}\left(1^{\prime}\right)$ & $82.7(4)$ & & \\
\hline & & & $\mathrm{N}(2)-\mathrm{Hg}-\mathrm{O}\left(1^{\prime}\right)$ & $79.9(4)$ & & \\
\hline
\end{tabular}

complex 2 forms crystals that are either colorless or ruby-red. The data presented here refer to the ruby-red specimen, as the colorless crystals proved inadequate for the X-ray experiment.

The X-ray diffraction data were collected at room temperature using graphite-monochromatized Mo- $K_{\alpha}$ radiation $(\lambda=0.71073 \AA)$ and corrected for Lorentz and polarization effects (1-3) and for absorption $(\mathbf{1}, \mathbf{2})$. For $\mathbf{3}$, a total of 36 frames were collected, each with a rotation of $6^{\circ}$ about $\phi$, an exposure time of $20 \mathrm{~min}$, and the detector position at $90 \mathrm{~mm}$ from the crystal, whereas data reduction and cell refinement were carried out using the programs DENZO and SCALEPACK. ${ }^{[45]}$ The structures were solved by means of the heavy-atom methods $(\mathbf{1}, \mathbf{2})$ or the direct methods $(3)$, using the SHELXTL-NT package, ${ }^{[46]}$ and were refined by full-matrix least-squares procedure on $F^{2}$ with the SHELXL-97 ${ }^{[47]}$ program. Scattering factors incorporated in SHELXL-97 were used; no empirical extinction corrections were applied.

In the last cycles of refinement of $\mathbf{1}$ and $\mathbf{3}$, all the non-H atoms were allowed to vibrate anisotropically. In 2 the ratio between the number of observed reflections and the number of parameters was unsatisfactory. Accordingly, the atoms belonging to the inner coordination core were refined anisotropically, while the remaining non$\mathrm{H}$ atoms were refined isotropically. As for $\mathrm{H}$ atoms, in $\mathbf{1}$ and $\mathbf{2}$ they were placed in idealized positions and refined with the "riding model." In both structures the $U_{\text {iso }}$ values of hydrogen atoms were set at 1.2 times $U_{\text {eq }}$ of the appropriate carrier atom. In $\mathbf{3}$, the $\mathrm{H}$ atoms were refined isotropically. The crystal data and refinement parameters of the three complexes are summarized in the Supporting Information (Table 1SI); none of the structures revealed any anomalous feature. Selected interatomic distances and angles are shown in Table 5 .

CCDC-642237 to -642239 contain the supplementary crystallographic data for this paper. These data can be obtained free of charge from The Cambridge Crystallographic Data Centre via www.ccdc.cam.ac.uk/data_request/cif.

Supporting Information (see also the footnote on the first page of this article): Details on acidity macro- and micro-constant and stability constant determination, UV/Vis spectra of the spectrophotometric titrations, X-ray crystallographic data.

\section{Acknowledgments}

The authors gratefully acknowledge the Colleagues of the Dipartimento di Scienze Chimiche of the University of Trieste (Italy), Profs. L. Randaccio, E. Zangrando, and S. Geremia, for kindly allowing access to their instrumentation for the X-ray diffraction data collection of complex 3. We also thank Dr. F. Ricchelli of the Dipartimento di Scienze Biologiche of the University of Padova (Italy) and Dr. Peter Nikolai of the Bulgarian Academy of Sciences for the helpful discussion and suggestions about the photochemical properties of the ligands and complexes.

[1] a) M. Patra, N. Bhowmik, B. Bandopadhyay, A. Sharma, Environ. Exp. Bot. 2004, 52, 199; b) K. Vig, M. Megharaj, N. Sethunathan, R. Naidu, Adv. Environ. Res. 2003, 8, 121.

[2] D. A. Suhy, T. V. O'Halloran in Metal-responsive Gene Regulation and the Zinc Metalloregulatory Model (Eds: A. Sigel, H. Sigel), Marcel Dekker, Basel, 1996, vol. 32, p. 557.

[3] E. Bakker, P. Bühlmann, E. Pretsch, Chem. Rev. 1997, 97, 3083.

[4] P. Bühlmann, E. Pretsch, E. Bakker, Chem. Rev. 1998, 98, 1593.

[5] O. S. Wolfbeis in Biomedical Optical Instrumentation and Laserassisted Biotechnology, Kluwer Academic Publisher, Dordrecht, 1996, pp. 327-337.

[6] U. E. Spichiger-Keller in Chemical Sensors and Biosensors for Medical and Biological Application, Wiley-VCH, Weinheim, 1997.

[7] A. W. Czarnik (Ed.) in Fluorescent Chemosensors for Ion and Molecule Recognition, ACS Symposium Series 538, ACS, Washington, DC, 1992.

[8] A. P. de Silva, H. Q. N. Gunaratne, T. Gunnlaugsson, A. J. M. Huxley, C. P. Mc Coy, C. P. J. T. Rademacher, T. E. Rice, Chem. Rev. 1997, 97, 1515.

[9] B. Valeur, I. Leray, Coord. Chem. Rev. 2000, 205, 3.

[10] a) C. Bargossi, M. C. Fiorini, M. Montalti, L. Prodi, N. Zaccheroni, Coord. Chem. Rev. 2000, 208, 17; b) L. Prodi, F. Bolletta, M. Montalti, N. Zaccheroni, Coord. Chem. Rev. 2000, 205, 59; c) M. Montalti, L. Prodi, N. Zaccheroni in Handbook of Photochemistry and Photobiology (Eds.: M. S. A. Abdel-Mottaleb, H. S. Nalwa), American Institute of Physics, Stevenson Ranch, 2003, 3, 271-371. 
[11] a) C. J. Fahrni, T. V. O'Halloran, J. Am. Chem. Soc. 1999, 121, 11448; b) R. B. Thompson, Curr. Opin. Chem. Biol. 2005, 9, 526.

[12] a) L. Canovese, F. Visentin, G. Chessa, A. Niero, P. Uguagliati, Inorg. Chim. Acta 1999, 293, 44; b) L. Canovese, F. Visentin, G. Chessa, P. Uguagliati, C. Levi, A. Dolmella, G. Bandoli, Organometallics 2006, 25, 5355.

[13] D. C. Bebout, A. E. DeLanoy, D. E. Ehmann, M. E. Kastner, D. A. Parrish, R. J. Butcher, Inorg. Chem. 1998, 37, 2952.

[14] S. M. Berry, D. C. Bebout, R. J. Butcher, Inorg. Chem. 2005, 44, 27.

[15] C. K. Johnson, ORTEP, Report ORNL-5138, Oak Ridge National Laboratory, Oak Ridge, TN, 1976.

[16] A. W. Addison, T. N. Rao, J. Reedijk, J. R. Rijn, G. C. Verschoor, J. Chem. Soc. Dalton Trans. 1984, 1349.

[17] IUPAC Provisional Recommendations, Nomenclature of Inorganic Chemistry, Draft March 2004, available at www.IUPAC.org.

[18] a) R. S. Cahn, C. Ingold, V. Prelog, Angew. Chem. Int. Ed. Engl. 1966, 5, 385, 511; b) V. Prelog, G. Helmchen, Angew. Chem. Int. Ed. Engl. 1982, 21, 567.

[19] F. H. Allen, Acta Crystallogr., Sect. B 2002, 58, 380-388; Cambridge Structural Database (Version 5.26 of November $2004+$ two updates).

[20] A. J. Blake, E. C. Pasteur, G. Reid, M. Schroder, Polyhedron 1991, 10, 1545 (refcode VUGHEK).

[21] J. Pickardt, L. von Chrzanowski, R. Steudel, M. Borowski, Z. Naturforsch. B: Chem. Sci. 2004, 59, 1077 (refcode QAHNIX).

[22] M. E. Sobhia, K. Panneerselvam, K. K. Chacko, I. Suh, E. Weber, C. Reutel, Inorg. Chim. Acta 1992, 194, 93 (refcode KUSMAM).

[23] J. Halfpenny, Acta Crystallogr., Sect. B 1982, 38, 2049 (refcode BICMUV).

[24] E. R. T. Tiekink, Z. Kristallogr. - New Cryst. Struct. 2001, 216, 439 (refcode MIVJEG)

[25] M. Vetrichelvan, L.-H. Lai, K. F. Mok, Eur. J. Inorg. Chem 2004, 2086 (refcode AXOJAY).

[26] D. C. Craig, Y. Farhangi, D. P. Graddon, N. C. Stephenson, Cryst. Struct. Commun. 1974, 3, 155 (refcode BBPYHG).

[27] D. Matkovic-Calogovic, N. Davidovic, Z. Popovic, Z. Zugaj, Acta Crystallogr., Sect. C 1998, 54, 1766 (refcode SAVQOV).

[28] T.-F. Liu, H.-K. Lin, S.-R. Zhu, Z.-M. Wang, H.-G. Wang, H.W. Sun, X.-B. Leng, Y.-T. Chen, J. Mol. Struct. 2002, 605, 117 (refcode UHARIE).

[29] M. Pitie, C. Boldron, H. Gornitzka, C. Hemmert, B. Donnadieu, B. Meunier, Eur. J. Inorg. Chem. 2003, 528 (refcode WUTFAS).

[30] A. Angeloff, J.-C. Daran, J. Bernadou, B. Meunier, Eur. J. Inorg. Chem. 2000, 1985 (refcode DUHHAP).

[31] A. Hazell, C. J. McKenzie, L. P. Nielsen, J. Chem. Soc. Dalton Trans. 1998, 1751 (refcode NOZGOY).

[32] D. Schnieders, M. Merkel, S. M. Baldeau, B. Z. Krebs, Z. Anorg. Allg. Chem. 2004, 630, 1210 (refcodes OBOCIS, OBOCOY).

[33] E. Amadei, M. Carcelli, S. Ianelli, P. Cozzini, P. Pelagatti, C. Pelizzi, J. Chem. Soc. Dalton Trans. 1998, 1025 (refcode PULPAN).
[34] M. Herceg, B. Matkovic, D. Sevdic, D. Matkovic-Cologovic, A. Nagl, Croat. Chem. Acta 1984, 57, 609 (refcode CUYNAL).

[35] A. J. Blake, G. Reid, M. Schroder, Polyhedron 1990, 9, 2931 (refcode VOBSEK).

[36] A. J. Blake, A. J. Holder, T. I. Hyde, G. Reid, M. Schroder, Polyhedron 1989, 8, 2041 (refcode KIFCAD).

[37] D. Matkovic-Calogovic, Z. Popovic, B. Korpar-Colig, J. Chem. Crystallogr. 1995, 25, 453 (refcode ZUWPEM).

[38] M. Saladini, L. Menabue, E. Ferrari, D. Iacopino, J. Chem. Soc. Dalton Trans. 2001, 1513 (refcode QIXSUL).

[39] C. J. Baylies, L. P. Harding, J. C. Jeffery, T. Riis-Johannessen, C. R. Rice, Angew. Chem. Int. Ed. 2004, 43, 4515 (refcode IBIWAS).

[40] P. Gans, A. Sabatini, A. Vacca, Talanta 1996, 43, 1739.

[41] A. E. Martell, R. M. Smith in Critical Stability Constants, Plenum Press, New York, 1977, vol. 3.

[42] a) A. E. Martell, R. M. Smith in Critical Stability Constants, Plenum Press, New York, 1977, vol. 4; b) G. Anderegg, E. Hubmann, N. G. Podder, F. Wenk, Helv. Chim. Acta 1977, 60, 123.

[43] a) J. R. Lakowicz in Principles of Fluorescence Spectroscopy, 2nd ed., Plenum Press, New York, 1999; b) C. A. Parker in Photoluminescence of Solutions, Elsevier, Amsterdam, 1968; c) D. Sutherland, C. Compton, J. Org. Chem. 1952, 17, 1257; d) S. F. Mason, J. Chem. Soc. 1962, 493; e) B. L. Van Duuren, Chem. Rev. 1963, 63, 325; f) E. A. Steck, G. W. Ewing, J. Am. Chem. Soc. 1948, 70, 3397; g) K. M. Hendrickson, T. Rodopoulos, P. A. Pittet, I. Mahadevan, S. F. Lincoln, A. D. Ward, T. Kurucsev, P. A. Duckworth, I. J. Forbes, P. Zalewski, W. H. Betts, J. Chem. Soc. Dalton Trans. 1997, 3879; h) C. J. Fahrni, T. V. O'Halloran, J. Am. Chem. Soc. 1999, 121, 11448; i) S. Basu, "Theory of Solvent Effects on Molecular Electronic Spectra" in Advances in Quantum Chemistry, Academic Press, New York, 1964, vol. 1.

[44] a) A. P. De Silva, H. Q. N. Gunaratne, T. Gunnlaugsson, A. J. M. Huxley, C. P. McCoy, J. T. Rademacher, T. E. Rice, Chem. Rev. 1997, 97, 1515; b) C. Bazzicalupi, A. Bencini, A. Bianchi, C. Giorgi, V. Fusi, B. Valtancoli, M. Bernardo, F. Pina, Inorg. Chem. 1999, 38, 3806; c) M. C. Aragoni, M. Arca, F. Demartin, F. A. Devillanova, F. Isaia, A. Garau, V. Lippolis, F. Jalali, U. Papke, M. Shamsipur, L. Tei, A. Yari, G. Verani, Inorg. Chem. 2002, 41, 6623; d) J. M. Castagnetto, J. W. Canary, Chem. Commun. 1998, 203.

[45] Z. Otwinowski, W. Minor, "Processing of X-ray Diffraction Data Collected in Oscillation Mode" in Methods in Enzymology, vol. 276: Macromolecular Crystallography (Eds.: C. W. Carter Jr, R. M. Sweet), Academic Press, New York, 1997, part A, pp. 307-326.

[46] G. M. Sheldrick, SHELXTL NT, Version 5.10, Bruker AXS Inc., Madison, WI, 1999.

[47] G. M. Sheldrick, SHELXL-97, Program for the Refinement of Crystal Structures, University of Göttingen, Germany, 1997.

Received: February 20, 2007

Published Online: June 29, 2007

Please note that minor changes have been made to this publication in the European Journal of Inorganic Chemistry initial Early View version.

The Editor 